\title{
NAMING OF PARTS: THE USE OF FOSSIL-TAXA IN PALAEOBOTANY
}

\author{
CHRISTOPHER J. CLEAL ${ }^{1, *}$, BARRY A. THOMAS² \\ 'School of Earth Sciences, Life Sciences Building, Tyndall Avenue, Bristol, BS8 1TQ, United Kingdom; e-mail: chris.cleal@bristol.ac.uk. \\ ${ }^{2}$ Institute of Biological, Environmental \& Rural Sciences, Aberystwyth University, Penglais, Aberystwyth SY23 1NP, United Kingdom; \\ e-mail: bat@aber.ac.uk. \\ ${ }^{*}$ corresponding author
}

Cleal, C. J., Thomas, B. A. (2021): Naming of parts: the use of fossil-taxa in palaeobotany. - Fossil Imprint, 77(1): 166-186, Praha. ISSN 2533-4050 (print), ISSN 2533-4069 (on-line).

\begin{abstract}
Fossil plants are extinct plants whose remains (referred to as plant fossils) are found preserved in sedimentary deposits. Plant fossils are classified using fossil-taxa as defined in the International Code of Nomenclature. Fossil-taxa differ conceptually from taxa of living plants in that they often do not refer to whole organisms, but to the remains of one or more parts of the parent organism, in one or more preservational states. There can be complications when two parts of a plant are shown to be connected, or when two preservational states are correlated, and to avoid disrupting the wider palaeobotanical taxonomy it is often best to keep the fossil-taxa separate. Extinct fossil plants reconstructed by piecing together the plant fossils are best not given formal Linnean taxonomic names. There can also be problems using living plant taxa for fossils, even when there is a close morphological similarity of particular plant parts. Fossil-taxa for different plant parts can reflect different taxonomic ranks of the parent plants so care must be taken when using such taxa in floristic or phylogenetic studies. Because of taphonomic factors, a number of "artificial" fossil-taxa have proved useful, despite that they do not fully reflect the systematic positions of the parent plants.
\end{abstract}

Key words: palaeobotany, nomenclature, fossil-taxa

Received: May 11, 2021 | Accepted: September 17, 2021 | Issued: December 9, 2021

\section{Introduction}

At the time of writing (2020) we are celebrating the bicentenary of the birth of scientific palaeobotany as represented by the publication of the pioneering works of Sternberg (1820), Schlotheim (1820) and shortly afterwards Brongniart (1822). Extracting data from plant fossils to better understand past vegetation is obviously a key aspect of the subject for which many technical advances have been made (for summaries see Jones and Rowe 1999, Cleal and Thomas 2019). Also of fundamental importance, however, is the taxonomy of the fossils as this is central to communicating the observed relationships of the things being studied; without such classifications the observations are merely isolated facts of little epistemological value. Being the remains of plants, palaeobotanists before the 1820 s tended to classify the fossils in the same way as living plants, evidently thinking of them as conceptually little different from herbarium specimens (Stafleu 1967). However, with improved understanding of the various taphonomic processes responsible for changing plants into fossils, it became evident that this was oversimplistic and a different taxonomic approach was needed - this was one of major insights of Sternberg and Brongniart.

Although the essence of palaeobotanical taxonomy is still essentially as Sternberg and Brongniart proposed, there have been changes in detailed approach, especially since the 1950s. There have been several discussions on the subject (e.g., Cleal 1986, Chaloner 1986, 1999, Thomas 1989, Bateman and Hilton 2009, Cleal and Thomas 2010a) but in our opinion there is still some confusion as to the ontological nature of palaeobotanical taxa and how they are used in practice. This paper will review the current position, especially following the changes that were introduced in the 2012 International Code of Nomenclature for Algae, Fungi, and Plants (hereafter referred to as the ICN - McNeill et al. 2012). We will restrict our discussion to the situation relating to plant and fungus macrofossils because palynological taxonomy and nomenclature have been recently reviewed by Gravendyck et al. (2021).

\section{Historical background}

The earliest palaeobotanical publications (e.g., Lhuyd 1699, Scheuchzer 1709, Parkinson 1804, Schlotheim 1804; see Andrews (1980) for an historical review) tended to avoid the problems of classifying plant fossils, either by not naming them or naming them as extant species. However, as Schlotheim (1820), Sternberg (1820) and Brongniart (1822) pointed out (Text-fig. 1) any comparison with extant 

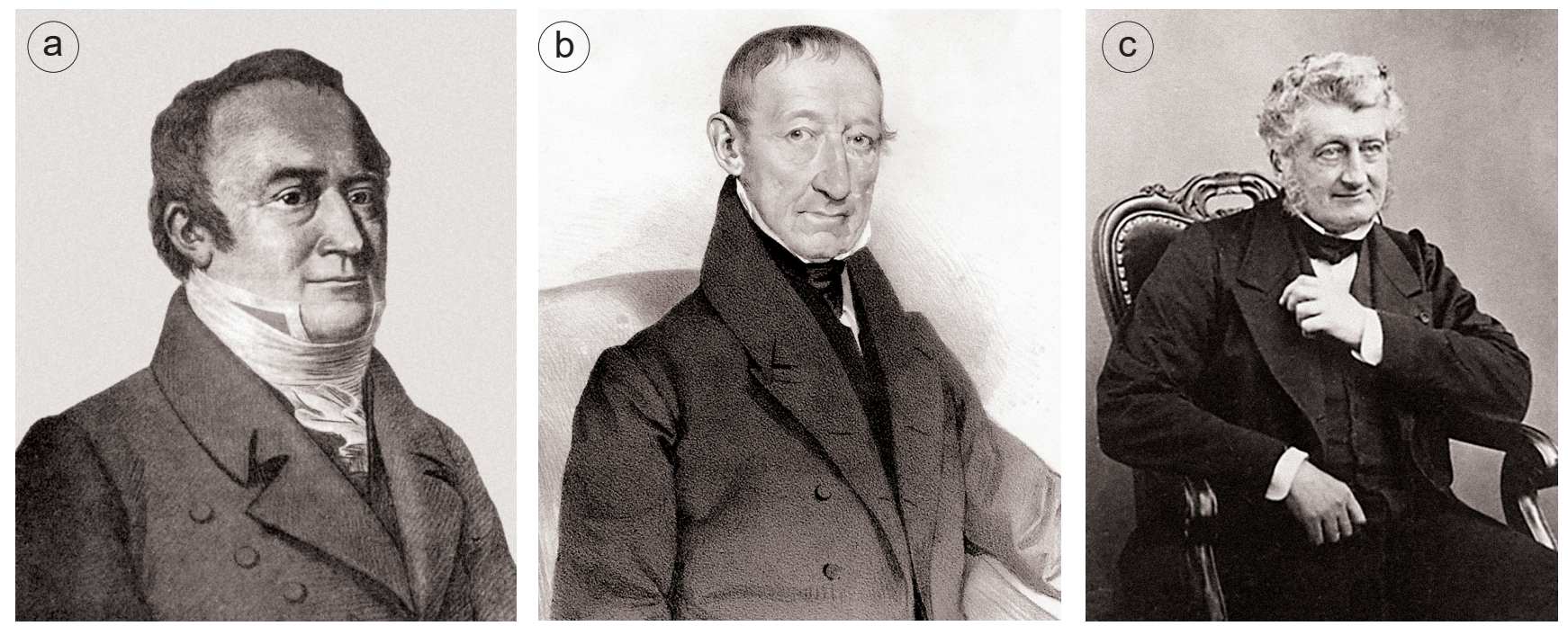

Text-fig. 1. The pioneers of scientific palaeobotany whose ideas laid the foundations of how we now name plant fossil-taxa. a: Ernst von Schlotheim (1764 - 1821); b: Kaspar Maria von Sternberg (1761 - 1837), reproduced by permission from J. Kvaček (National Museum, Prague); c: Adolphe Brongniart (1801 - 1876). Adapted from Cleal and Thomas (2019: fig. 2.1).

plants is of little value if it is not supported by reproductive structures.

Schlotheim (1820) introduced several generic names suggesting comparisons between certain fossils and extant plants, but without making definite statements as to the affinities of those fossils: for instance, Palmacites referred to remains of flabelliform leaves similar to those of the extant European fan-palms, and pinnate fern-like fronds were named Filicites. Schlotheim (1820) also established genera for plant remains whose affinities were totally ambiguous, such as Carpolithes for isolated seeds or ovules. Schlotheim (1820) unfortunately failed to validly publish these names (Kvaček 1982) but many were later validated by Brongniart (1822) within an improved classification for plant fossils (reviewed by Cleal and Thomas 2018). Importantly, Brongniart (1822) was explicit that his genera consisted of the remains of particular plant parts (e.g., leaves or seeds) and were not intended to represent whole organisms. The Brongniart (1822) classification was further expanded by Sternberg (1825) and Brongniart (1828a), and became the foundation of the palaeobotanical taxonomy still used today.

Although the resulting taxa of plant fossils were fundamentally different from the whole organism taxa used for living plants, the way that the two types of taxa were named was essentially the same. The early rules of botanical nomenclature (e.g., Candolle 1867, Briquet 1906) were intended to apply to taxa of plant fossils as well as of living plants, and included no special provisions to take into account the problems faced by palaeobotanists; few if any palaeobotanists seem to have been involved with the formulation of these rules. The situation started to change with proposals made by Thomas (1935) and Jongmans et al. (1935) who argued for the recognition of special types of taxa for use with plant fossils that were to be known as organ-genera and form-genera. A version of these proposals was eventually included in the first International Code of Botanical Nomenclature (Lanjouw et al. 1952; see comments by Malécot 2008) but there then followed a labyrinthine debate extending over half a century about exactly what was meant by these terms (summarised by Bateman and Hilton 2009 and Cleal and Thomas 2010a); in successive editions of the Code their definitions were changed, organgenera were removed, and a new concept of morphotaxa was introduced. The result was that many palaeobotanists ignored the concepts of organ-genera, form-genera and morphotaxa, and simply assigned fossils to what they thought were whole-plant genera and species; but this was overlooking the effect that taphonomy was having on the data that were available for classifying the fossils compared with that used with living plant.

To try to clear up this confusion, Cleal and Thomas (2010b) proposed changes to how plant fossil taxonomic nomenclature should operate and these have now been adopted in the ICN (Turland et al. 2018). Following the principle suggested by Chaloner et al. (1998) there are now special taxa at all ranks for classifying plant fossils. These are called fossil-taxa and have the following definition (ICN, Art. 1.2): "A taxon (diatom taxa excepted) the name of which is based on a fossil type is a fossil-taxon. A fossil-taxon comprises the remains of one or more parts of the parent organism, or one or more of their life-history stages, in one or more preservational states, as indicated in the original or any subsequent description or diagnosis of the taxon." In essence, other than that its name must be based on a fossil specimen, a fossil-taxon can be whatever palaeobotanists decide it should be (just as a taxon of living plants can be whatever botanists decide). Some regret has been expressed as to the loss of organ-genera and formgenera (Bateman and Hilton 2009). In reality, however, these concepts are merely end-members of the continuous spectrum of taxonomic concepts now included within fossilgenera, and it is difficult to see what benefits are to be gained by a sharp demarcation between them.

\section{What are we classifying?}

Taxonomy can refer to the classification of anything (e.g., Olivares 2011) but is mostly used in the context of 

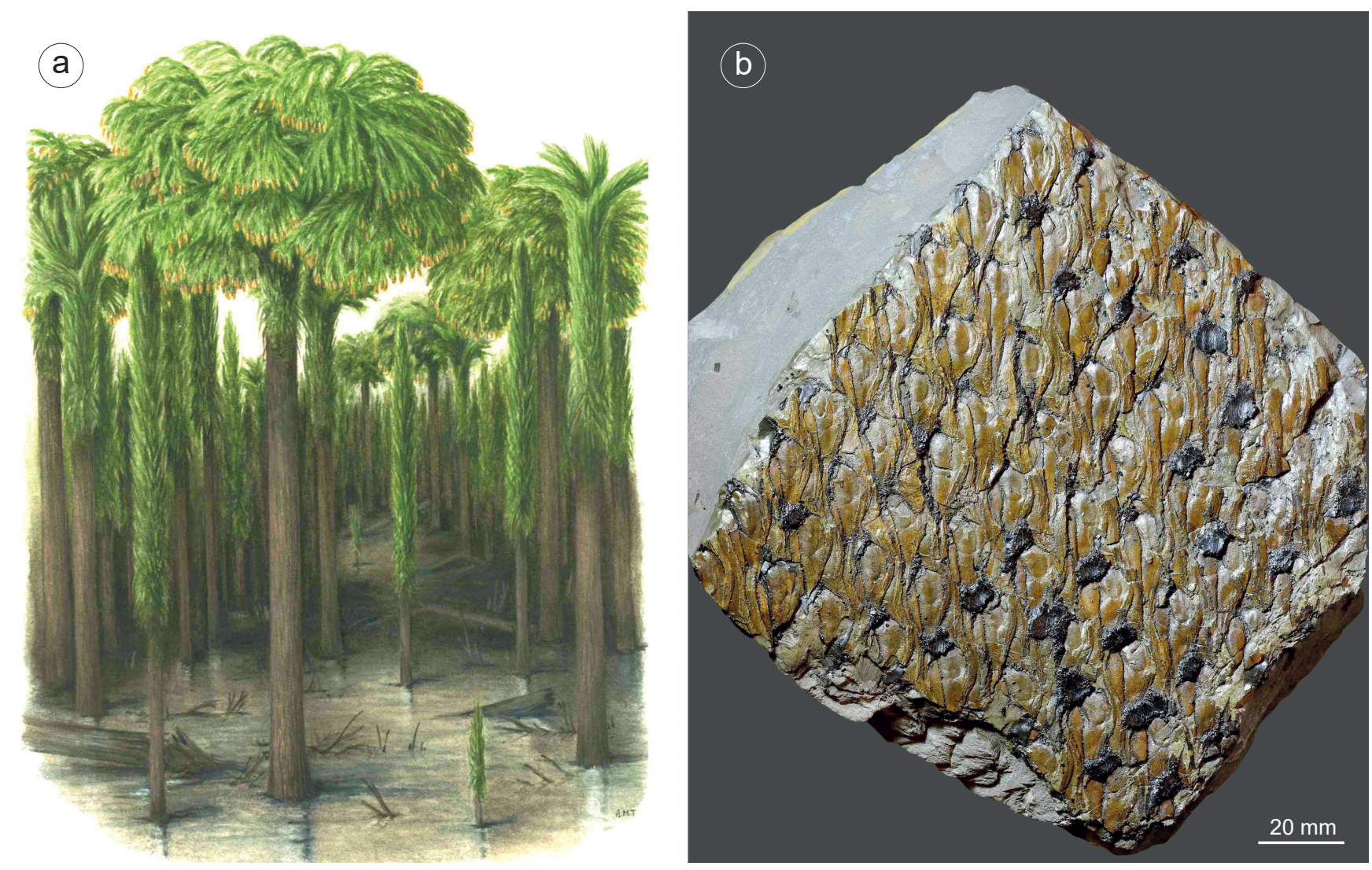

Text-fig. 2. The distinction between fossil plants (a) and plant fossils (b). a: Reconstruction of a late Carboniferous arborescent lycopsid, often referred to as the Lepidodendron-tree; artwork by A. Townsend (formerly of National Museum Wales, Cardiff, UK; see Townsend et al. 1998); b: Lepidodendron aculeatum STERnв.; Middle Coal Measures Formation (Duckmantian - upper Bashkirian), Brymbo, near Wrexham, UK (see Thomas et al. 2020: fig. 16b); National Museum Wales specimen 2013.43G.88.

organismal classification. Although some of the philosophical underpinning of biological taxonomy remains contentious (Kendig and Witteveen 2020) most biologists still agree with Huxley (1942) that it should aim to classify organisms into a hierarchical system that reflects their phylogenetic (i.e., cladistic) relationships (Williams and Ebach 2020). However, this overlooks another important practical function of taxonomy - to facilitate the identification and naming of organisms. Plant identifications are still usually based on morphological and anatomical criteria, now supplemented by DNA barcoding (e.g., de Vere et al. 2015). Although morphological and anatomical similarities can reflect phylogenetic relationships, adaptive convergence and divergence mean this correlation is rarely perfect. Consequently, a distinction is often drawn between natural (phylogenetic) and artificial (morphological/anatomical) classifications, the latter sometimes being referred to as parataxonomies (e.g., Sylvester-Bradley 1958, Meyen 1987).

However, this demarcation between natural and artificial taxonomies is itself artificial. All taxonomies are artificial (i.e., man-made) constructs designed to interpret observed patterns in the natural or wider world. In palaeobotany, taxa are developed based on morphological, anatomical and/or histological characters observed in the fossils these are, after all, the only empirical data available to the palaeobotanist. The choice and weighting of characters that are used to develop the taxonomies are subjective decisions, but the aim is usually to emphasise those characters thought to reflect the natural relationships of the parent plants. This is important not only for phylogenetic studies; even when the fossils are being used for biostratigraphy, palaeoecology or palaeogeography, the taxonomy will be far more useful if it is reflecting the phylogenetic relationships of the plants in the parent vegetation. It is notable that in palynology, where strictly morphological taxonomies have been developed (e.g., Hughes and Moody-Stuart 1969, Hughes 1970), they have not been widely adopted. However, these natural relationships of the parent plants can never be verified empirically; we can hypothesise that a particular taxonomy is reflecting plant phylogeny by comparing character patterns such as by using parsimony or phenetic similarities, but it cannot be empirically proved. In our view, phylogenetic taxonomies are aspirations, but morphological/anatomical taxonomies are the realities.

To understand what palaeobotanists are dealing with in practice, it is important to differentiate between two quite different concepts (Text-fig. 2): plant fossils, which are the fossilised remains of plant fragments preserved in sedimentary deposits; and fossil plants, which were the now-extinct plants that produced the remains now preserved as fossils (note the change in tense of the verb used in the two definitions). Plant fossils are the tangible objects that are studied directly by palaeobotanists, who use a range of techniques to extract information about the morphology, anatomy and sometimes histology of the plant fragments 
Table 1. Fossil taxa assigned to different plant parts for six representative plant groups in the late Carboniferous tropical coal swamps. Adapted from Cleal et al. (2021).

\begin{tabular}{|c|c|c|c|c|c|c|c|}
\hline & & Lycospids & Calamites & Sphenophylls & Marattialeans & Medullosaleans & Cordaites \\
\hline \multicolumn{2}{|l|}{ Stems } & Lepidodendron & Calamites & \multirow{2}{*}{ Sphenophyllum } & Caulopteris & - & Artisia \\
\hline \multicolumn{2}{|l|}{ Foliage } & Cyperites & Annularia & & \multirow{3}{*}{ Cyathocarpus } & Alethopteris & Cordaites \\
\hline \multirow{2}{*}{$\begin{array}{l}\text { Reproductive } \\
\text { structures }\end{array}$} & Female & $\begin{array}{c}\text { Lepidocarpon } \\
\text { Lepidostrobophyllum }\end{array}$ & \multirow{2}{*}{ Calamostachys } & \multirow{2}{*}{ Bowmanites } & & Trigonocarpus & Cardiocarpus \\
\hline & Male & Lepidostrobus & & & & Whittleseya & Cordaitanthus \\
\hline \multicolumn{2}{|c|}{ Rooting structures } & Stigmaria & Pinnularia & - & - & - & - \\
\hline \multicolumn{2}{|l|}{$\begin{array}{l}\text { Total } \\
\text { fossil-genera }\end{array}$} & 6 & 4 & 2 & 2 & 3 & 4 \\
\hline
\end{tabular}

that formed the fossils. These data are then used to try to reconstruct and classify the parent fossil plants whose remains have been fossilised. The resulting taxonomy of fossil plants is then sometimes used as the basis for classifying the plant fossils. However, the reconstructions are hypothetical and incomplete conceptual models, and rarely provide a secure basis for the classification of the fossils, which are physical objects; the fossils are more than merely tokens of the parent organisms.

A more robust approach to palaeobotanical taxonomy is to classify the fossils using characters inherent and specific to the fossils themselves (Cleal and Thomas 2010a). As the fossils are tangible objects, their classification can be subjected to direct and complete scientific testing in a way that a classification of the partial, hypothetical reconstructions cannot. The aim is often to make the classification of the plant fossils reflect at least partly what is thought to be the systematic relationships of the fossil plants: for instance, the classification of Palaeogene paratropical fossil seeds has been argued to mirror closely that of extant tropical trees (Reid and Chandler 1933, Collinson 1983). But in practice this correspondence is difficult to test and is often quite poor,

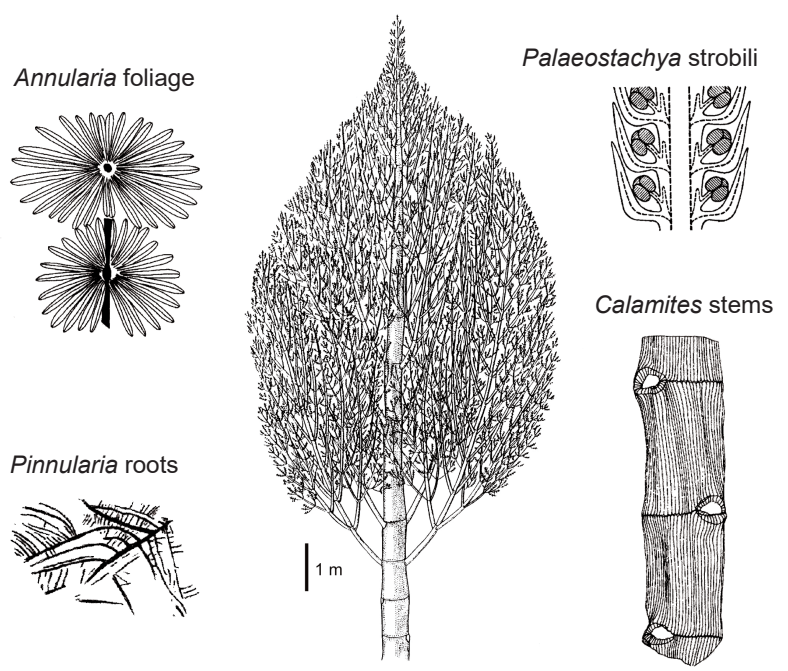

Text-fig. 3. Some of the fossil-genera produced by a Carboniferous arborescent sphenospid. Redrawn from Cleal and Thomas (2019). especially with remains of older plant groups: for instance, the fossil-species taxonomy of Carboniferous sphenopsid stems (Stur 1887, Jongmans 1911, Crookall 1969) probably bears little relationship to the systematics of the parent trees. There is a continuous spectrum between how well or poorly the different types of palaeobotanical taxonomy reflect the botanical affinities of the parent plants, and it is obviously important to know where a particular taxon lies in this spectrum when trying to interpret it in a phylogenetic, floristic, palaeoecological or biostratigraphical context.

\section{Naming different plant parts}

The aspect of palaeobotanical taxonomy that nonspecialists often find counter-intuitive is that different parts of a plant can be assigned to different fossil-taxa (Tab. 1, Text-fig. 3). The confusion partly arises because it is often assumed that, when a taxonomic name is given to a fossil, it is referring to the parent plant from where the fossil came, whereas as we have shown it refers to the fossil which preserves only a part of the plant.

Assigning different parts of the plant to what are now known as fossil-taxa goes back to the pioneering work of Brongniart (1822, 1825) and Sternberg (1825), and arose because most plants fragment during fossilisation (Thomas 1989, Thomas and Cleal 1999, Forey et al. 2004); it is rare to find the different parts still attached to each other. Fragmentation is of course not unique to plant fossils: conodont animal remains are almost always found as dispersed elements (parts of their feeding-apparatuses) and Sylvester-Bradley (1954) argued that "parataxa" similar to form-genera (as used in the older botanical codes) might be applicable to their classification (see also Bengtson 1985). However, this has never been incorporated formally into palaeozoological taxonomy - fossil-taxa remain a distinct and distinctive feature of palaeobotany.

There are no formal rules about how a plant is divided up into its component sets of fossil-taxa. Sometimes it is fairly self-evident - when a particular organ is regularly abscised from the plant and preserved as a coherent structure (e.g., seeds) it makes sense to assign it to its own set of fossiltaxa. But compound structures can be more problematic. 
For instance, although cones and strobili are often abscised whole from the plant and have their own fossil-taxa, some also regularly disarticulated so their component parts can also occur as isolated fossils: Carboniferous Lepidocarpon D.H.ScotT (Scott 1900) strobili regularly disaggregated as part of the plant's dispersal strategy (Text-fig. 4) and so the resulting isolated sporophylls are assigned to the fossilgenus Lepidostrobophyllum HiRMER (Hirmer 1927, Allen 1961, Boulter 1968, Habgood et al. 1998); in the same way, isolated leaf-scales that subtended Mesozoic bennettitalean "flowers" such as Williamsonia CARRUTH. (Carruthers 1870) are assigned to Cycadolepis SAPORTA (e.g., Saporta 1874, Harris 1969, Watson and Sincock 1992). Although such isolated bracts and scale-leaves can be important for indicating the presence of a particular group of plants, it would be misleading to record them using fossil-taxa defined on the whole reproductive structures; for instance, not all Lepidostrobophyllum were produced by Lepidocarpon strobili.

Another factor that has to be taken into account is, will

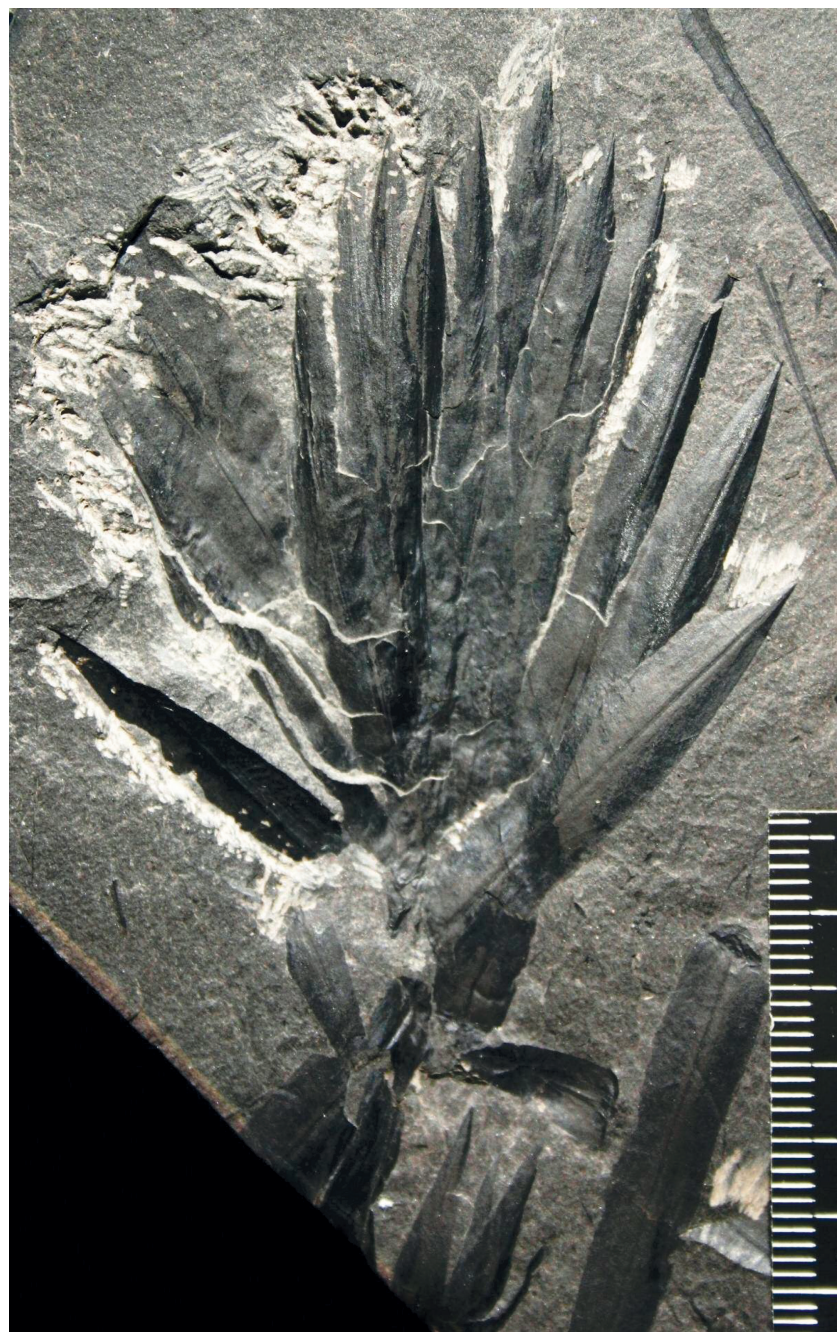

Text-fig. 4. Lepidocarpon cone in the process of disaggregating as part of the dispersal strategy of the plants. When preserved isolated, the sporophylls are assigned to the fossil-genus Lepidostrobophyllum. Refigured from Thomas (1981). Grovesend Formation (upper Asrturian - lower Moscovian), Kilmersdon Tip, Radstock Coalfield, UK; Natural History Museum (London) specimen V.60431. having separate fossil-taxa for particular isolated plant parts be useful to palaeobotanists? For example, medullosalean fronds that abound in the upper Carboniferous fossil-record represent clearly-defined organs but are usually found as isolated pinnae or even pinnules. Consequently, most early classifications tended to be based on characters of the individual pinnae and pinnules (e.g., Brongniart 1822, 1828a). Such taxa were useful for recording the presence of particular frond fragments but they ultimately proved to be of little practical value for understanding the systematics of the parent plants, which in turn reduced their value for biostratigraphical and floristic studies. Improved generic schemes were subsequently developed using architectural characters of the complete fronds reconstructed from the fossil fragments (e.g., Gothan 1941, Laveine 1997). The fronds of only a few fossil-species have been reconstructed, and assigning the other species has had to be based on comparisons using criteria such as epidermal structure preserved in cuticles (e.g., Cleal et al. 1990, Cleal and Shute 2012) or on evidence of association of other frond parts such as cyclopterid epiphytic leaves (e.g., Laveine 2005). This has allowed the vast majority of the known fossil-species defined on isolated pinnae to be placed in the classification based on frond-architecture (Cleal and Shute 1995, 2012).

An alternative solution was proposed by Gothan (1953) based on the trinomial taxonomic nomenclature used by Kidston (1884) for fern fossils: for instance, "Neuropteris (Imparipteris) heterophylla" indicated that the species had pinnules that corresponded to the fossil-genus Neuropteris (BRONGn.) STERnB. (Sternberg 1825) and a frond architecture corresponding to Imparipteris GotHAN (Gothan 1941). A species with Neuropteris-like pinnules but for which frond architecture and cuticles are unknown would just use the first generic name, e.g., Neuropteris teberdensis SHCHEG. (Shchegolev 1979). However, viewed in the context of today's taxonomic nomenclature this would imply that the botanically more-meaningful Imparipteris was a subgenus of the more loosely defined Neuropteris, which it is not. Consequently, this nomenclatural approach has been generally rejected.

Alternative solutions are to use satellite taxa (discussed later under taxonomic rank) or open nomenclature as used in palaeozoology (Matthews 1973, Bengtson 1988). Using the open nomenclature scheme suggested by Matthews (1973), Laveineopteris? dussartii (LaveIne) LAVEInE (Laveine 2005) would imply that the transfer of the species to Laveineopteris should be regarded as provisional because neither frond architecture nor cuticles are known. Although, this would not be possible with a new species as ICN Art. 35.2 states that a combination "is not validly published unless the author definitely associates the final epithet with the name of the genus or species", it does offer a solution when taxonomically revising previously published species. However, it should be noted that an open nomenclature "?" has been used in a rather different context, for a fossil that agreed in all available data with a living taxon, but where certain critical criteria were absent (Collinson 1980). Evidently, if open nomenclature is to be adopted in palaeobotany, an agreed procedure will be needed but, as it deals with taxonomic rather than strictly nomenclatural issues, this is unlikely to be in the ICN (it is also not covered 
by the Zoological nomenclatural code - see comments by Sigovini et al. 2016).

\section{What happens when plant parts are correlated?}

As palaeobotany has advanced, the connection between organs in various plants has been demonstrated, either on direct evidence of attachment, or indirect evidence such as the regular co-occurrence of remains of plant parts, or similarities in anatomical or surface features (Chaloner 1986). But how should this be reflected in the taxonomic nomenclature? The least disruption to the taxonomy and nomenclature results from simply continuing to use the separate fossil-taxa for the different plant parts. For instance, both the heterosporous lycopsid cone Flemingites and the microsporangiate cone Lepidostrobus have been found attached to leafy shoots (e.g., Text-fig. 5), but most accounts merely list a named cone species attached to a named shoot (e.g., Chaloner 1953, Thomas and Seyfullah 2015a); the taxonomic and nomenclatural issues surrounding these lycopsid cone fossils are discussed later in the section on "Artificial" fossil taxa. However, palaeobotanists often seem to be drawn to the idea that the connection between the plant parts should be reflected in the taxonomy of the fossils and that this will improve understanding of the systematics of the parent plants, but this can often have unforeseen consequences.

It is perfectly legitimate to designate a new fossil-taxon for the combination of plant parts, but what should this new combination fossil-taxon be named? One option is to expand the circumscription of one of the existing fossil-taxa so it now includes both plant parts. Wang et al. (2009) described noeggerathialean foliage of the fossil-genus Paratingia HoNG ZHANG, 1987 with attached strobili from the lower Permian Wuda Tuff of north China, and established a combination fossil-genus for the foliage and strobili. There was at the time no valid generic name for the strobili (see comments by Pfefferkorn and Wang 2016) and so the only existing name of fossil-genus whose type could unequivocally be placed within the new combination fossil-genus was Paratingia. Since remains of Paratingia foliage appear to be not particularly diverse, it seems reasonable to assume that all plants with such foliage formed a systematically coherent group and bore the same strobili, and so expanding the circumscription of the foliage fossil-genus to include the strobili appeared reasonable.

Another similar example was where the circumscription of the peltaspermalean ovuliferous fossil-genus Autunia KrASSER (Krasser 1919) was expanded by Kerp (in Kerp and Haubold 1988a) to also include foliage. In this case, the generally-used generic name for this foliage (Callipteris BRONGN.; Brongniart 1849) was having to be supressed for nomenclatural reasons and so a new generic name would have been needed. The taxonomic revision proposed in Kerp and Haulbold (1988a) avoided the creation of such a new generic name, although a number of other names were needed for peltaspermalean-like fossil-genera for which fructifications were unknown (Kerp and Haulbold 1988a, b).

But other examples are more problematic. Sphenophyllum oblongifolium (GERMAR) UNGER (三 Sphenophyllites

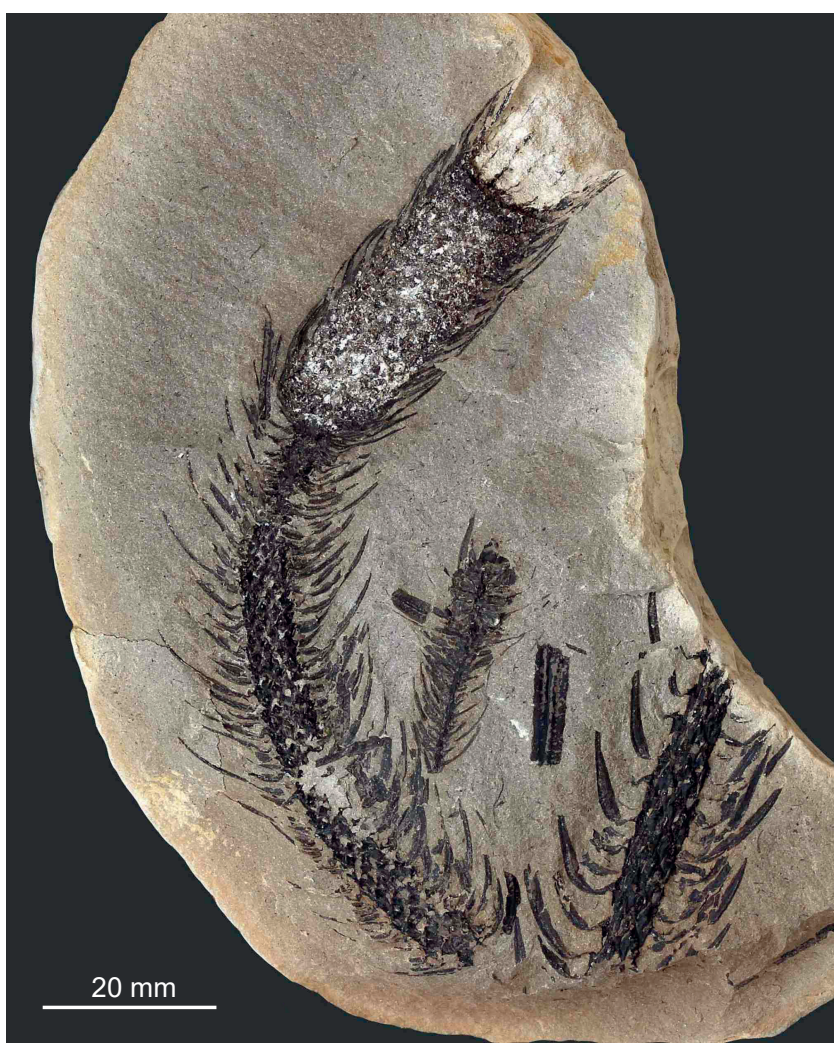

Text-fig. 5. Fossil remains of a leafy Lepidodendron ophiurus BRONGN. shoot bearing a Flemingites strobilus produced by a tree similar to that shown in Text-fig. 2a; Middle Coal Measures Formation (Duckmantian - upper Bashkirian), Brymbo, near Wrexham, UK (see Thomas et al. 2020: fig. 16b); National Museum Wales specimen 2013.43G.120.

oblongifolius GERMAR) (Germar 1845, Unger 1850) is a fossil-species of sphenophyllalean leafy shoots found widely in the Upper Pennsylvanian and Permian of Euramerica and China. Barthel $(1976,2015)$ reported a distinctive type of strobilus attached to $S$. oblongifolium shoots from the lower Permian of Germany. If found isolated, such strobili would normally be assigned to a species of Bowmanites BINNEY (Binney 1871), but Barthel (1976) instead emended the diagnosis and circumscription of $S$. oblongifolium so that it now included the strobili (he made no comment on the circumscription of the fossil-genus). However, Zodrow and Gao (1991) later reported other shoots of S. oblongifolium from the Middle Pennsylvanian of Cape Breton (Canada) that bore a different type of strobilus with much smaller, different-shaped sporophylls, each of which bore more sporangia; the Canadian fossils were, therefore, placed in a new fossil-species and fossil-genus, Leeites oblongifolis ZODROw et Z.F.GAO (this was clearly stated to be a new species, not just a new combination of the Germar species epithet with a new genus). Although the generic significance of these differences in strobili has been questioned (Libertín et al. 2014) the differences at the rank of species appear real. This clearly presents problems when isolated shoots are found: do they belong to S. oblongifolium sensu Barthel $(1976,2015)$ or L. oblongifolis? It might be argued that this is not a problem - that it is not necessary to have a valid species name for shoots without strobili. However, S. oblongifolium in its traditional sense refers to very distinctive and widely- 
reported leafy shoots with well-defined stratigraphical and geographical distributions, and the loss of this fossil-species would be detrimental to floristic and biostratigraphical studies. If only from a utilitarian perspective, it would seem to be preferable to retain separate fossil-taxa for the sphenophyllalean leafy shoots and the strobili.

Hoskins and Cross (1943) also tried to correlate sphenophyllalean shoots and strobili, but they instead changed the circumscription of the strobilus fossil-genus Bowmanites to include the shoots and proposed a series of new combinations of species formerly assigned to Sphenophyllum. The difficulty here is that the type species of Sphenophyllum ( $S$. emarginatum BRONGN.; Brongniart 1828a) bore Bowmanites strobili (e.g., Bek 2018) and so normal nomenclatural practice would require Bowmanites to be supressed in favour of the earlier published Sphenophyllum Brongn. (Brongniart 1828a). This would require all of the Bowmanites species to be transferred to Sphenophyllum, whether or not the leafy shoots were known. Again, the practical benefits of combining the fossil-taxa for the strobili and foliage would seem to be marginal, while the disruption to the taxonomy and nomenclature would be considerable.

An alternative solution for situations where plant parts are shown (or indicated) to have been originally connected is to create a completely a new fossil-taxon for the combination, but this can also introduce taxonomic problems. Zamites gigas (LindL. et Hutton) Morris (三 Zamia gigas LindL. et HutTon) (Lindley and Hutton 1835, Morris 1841) was established for fossil fronds resembling those of living cycads. Carruthers (1870) subsequently correlated these fronds with reproductive structures ("flowers"), and established a new genus Williamsonia to include both plant parts, with three species with names based on epithets whose types were fronds; of these, Williamsonia gigas (LindL. et HutTON) CARRUT. was later designated as the type (Seward 1917). The problem is that there are other Williamsonia-like bennettitalean flowers that have been correlated with different types of frond of the fossil-genera Ptilophyllum MORRIS (Morris 1840) and Pterophyllum Brongn. (Brongniart 1825) (e.g., Harris 1969, Watson and Sincock 1992); it is also far from certain that all Zamites fronds were borne on plants with Williamsonia flowers. If we were to retain Williamsonia as a combination fossilgenus for fronds and flowers it would, therefore, either have to have (1) a very wide circumscription to include a wide range of fronds and flowers currently placed in different genera or (2) a very narrow circumscription restricted to those bennettitaleans with only Zamites fronds and only Williamsonia-like flowers. Neither solution is taxonomically satisfactory and Harris (1969) argued that is it far more sensible for Williamsonia to be restricted to the fossils of bennettitalean flowers and the fronds assigned to one or other of their own set of fossil-genera. Although sensible, to do this it has been necessary to conserve the name Williamsonia with a different type (Zijlstra and van Konijnenburg-van Cittert 2020). None of this confusion would have arisen if Carruthers (1870) had not tried to create a combination fossil genus for the fronds and flowers.

Another series of fossils from the Wuda Tuff showed connections between stems, leafy shoots and strobili of a subarborescent sphenophyte, and was the basis of a combination fossil-species that was called Palaeostachya guanglongii Li LiU, PŠENIČKA, BeK, M.WAN, PfEFFERK. et JUN WANG bis. No emended diagnosis was provided but by inference Liu et al. (2021) were expanding the circumscription of the fossil-genus Palaeostachya; previously it had been restricted to strobili, but now it was to also include stems and leafy shoots. There is nothing intrinsically illegitimate about changing the circumscription of a fossil-genus in this way but, in this case, it will cause significant practical taxonomic difficulties. It is implicit in the Liu et al. (2021) proposal that Palaeostachya must include both the remains of this distinctive Chinese sphenophyte and the remains associated with the generic type (Palaeostachya elongata (C.PRESL) C.E.WEISs) (Weiss 1876) but, as pointed out by Liu et al., they were produced by plants with two very different growth strategies. Unless the name Palaeostachya were to be formally conserved with a new type (with all of the species formerly included within Palaeostachya requiring a new fossil-genus and new combinations), the inevitable consequence of their proposal is that all arborescent ("calamitid") sphenophytes will have to be included in a single whole-plant genus, irrespective of their significantly different growth strategies, which systematically makes little sense. What evidently seemed to be a logical solution to a problem encountered in one particular fossil flora has the potential for causing confusion for the wider palaeobotanical community.

An alternative approach was taken by Weiss (1884), who described numerous Carboniferous sphenophyte fossils linking stems, foliage and strobili. To demonstrate these relationships, he used the same species epithet but combined with a different generic name for each plant part: for instance, he described stems as Calamites ramosus Artis (Artis 1825), the attached foliage as Annularia ramosa C.E.WEIss and the strobili as Calamostachys ramosa C.E.WEISs. Unfortunately, it was not clear from his descriptions if he was regarding these as one species but assigned to a different genus according to which plant part was being referred to (which goes against normally accepted nomenclatural practice that a species can only belong to one genus), or that there were three separate fossil-species with the same epithet but placed in different fossil-genera. It is not formally illegitimate to name different fossil-species for different plant parts using the same epithet but assigned to different fossil-genera, but those species must be clearly and separately diagnosed and typified, which Weiss failed to do. Because it is not clear how Weiss (1884) was envisaging the circumscription of these fossil-taxa it has proved difficult to use them in practice (Jongmans 1911).

Yet another solution has been to place fossil-species for different plant parts in genera with names with a similar root but with suffixes indicating what plant parts are being referred to. This again is totally legitimate within the nomenclatural rules and in some cases can be taxonomically acceptable, but in other cases can cause difficulties. Renier and Stockmans (in Renier et al. 1938) established Ulostrobus for cones attached terminally to slender, leafy shoots that Renier (1926) had earlier identified as Ulodendron RENIER et Stockmans. However, Thomas (1967) showed that the Renier (1926) leafy shoots do not belong to Ulodendron sensu Lindley and Hutton (1832), in which the wider stems 
have persistent leaves; they are, in fact, terminal shoots of Lepidodendron which abscised its leaves from the wider stems (Thomas and Seyfullah 2015a). The type of Ulostrobus is, therefore, a strobilus attached to a Lepidodendron shoot and is morphologically indistinguishable from the other strobili found attached to Lepidodendron and normally placed in Flemingites (Text-fig. 4). The name Ulostrobus is therefore both nomenclaturally misleading (it does not refer to the strobili attached to Ulodendron) and is almost certainly a later heterotypic synonym of Flemingites.

In conclusion, when two or more plant parts are shown to be in organic connection or can be reliably correlated by other means (e.g., similarity of epidermal structures), there are three main options: (1) keep the fossil-taxa for the different plant parts separate; (2) emend the diagnosis of the fossil-taxon used for one of the plant parts so that its circumscription becomes expanded to include the other plant part(s); or (3) create a new fossil-taxon to include all the plant parts. There are no fixed rules for deciding which option to follow but the guiding principle should clearly be to try to avoid causing significant disruption to the taxonomy. For instance, expanding the circumscription of a fossil-taxon of foliage to include strobili might appear attractive if an example of connectivity has been found, but it might cause significant disruption to the widely-used taxonomy of the foliage, requiring numerous new combinations to be created.

\section{Whole-plant reconstructions}

A related problem is how to name the whole-plant reconstructions that regularly appear in palaeobotanical and other textbooks (e.g., Text-figs 2a, 3, 6b). Reconstructions of the smaller, herbaceous species may be based on more or less complete fossilised remains of the plants, notably among Devonian taxa (e.g., Lele and Walton 1961) but also in some younger floras (e.g., Barthel 1968, Pšenička et al. 2021); these can potentially be named and classified in the same way as any plant fossil. Rarely, larger, subarborescent plants have been found at least partly complete, such as when they have been very rapidly preserved in situ by volcanic ash-fall (e.g., Liu et al. 2021). However, these are exceptions and the vast majority of larger plants have been reconstructed by connecting their component parts through evidence of co-association or similarity in anatomical features (e.g., Kvaček 2008, Bomfleur et al. 2013). Even the best examples of these are mostly only gross-morphological reconstructions showing the form of the plants; only rarely is the cellular structure also fully-preserved. Ultimately, most such whole-plant reconstructions based on the plant fossil record are theoretical "biofantasies" (DiMichele and Gastaldo 2008) that exist just as hypothetical constructs in the minds of palaeobotanists, or as illustrations or models created by artists (Townsend et al. 1998).

When such reconstructions are published in the literature, they are often given a Linnean-style taxonomic name usually based on the name of one of the best-known component fossil-taxa: for instance, reconstructions of one of the Carboniferous arborescent lycopsids (Text-fig. 2a) are often named Lepidodendron, after the fossil-genus used for the stem adpressions (Text-fig. 2b); Unger (1850) even emended the diagnosis of Lepidodendron to include the whole plant. This may seem a straightforward and harmless validation of the legitimacy of the reconstruction. However, if this was to be regarded as a change in the formal use of the name Lepidodendron, it implies a change in the generic diagnosis so that it also includes the other organs such as strobili, foliage and rooting-structures (Thomas and Cleal 2020). If this was accepted, many of the Lepidodendron species for which the associated other plant parts are unknown could not be safely included within the new genus, and a new genus and name would be required for these less well-understood fossils. The resulting flurry of new combinations would cause significant nomenclatural disruption and could be ignored by many palaeobotanists.

If this was to be a real gain for palaeobotany, helping improve the understanding of the systematics of the plants, then this disruption might be regarded as a price worth paying. However, it is difficult to see what real scientific gain is to be obtained by assigning a formal Linnean taxonomic name (implying a binomial) to such a reconstruction. Linnean taxonomic names are not merely labels to identify a particular organism; they are part of a systematic hierarchy within which the organisms are classified either phylogenetically or morphologically, and this implies there are numerous similar organisms to form that hierarchy. In this case, there are only a small number of reconstructed fossil plants, most of which are monotypic at the rank of genus and even family, and so there is no taxonomic hierarchy in which to place them much below the rank of order. There are of course living monotypic families and genera of living organisms that are assigned binomial Linnean taxonomic names, and there is nothing formally to prevent this from being done for the reconstructed fossil plants, but the question must be asked, what is to be gained scientifically?

This is not to disparage the development of whole-plant reconstructions, but what is the real scientific justification of providing them with a formal Linnean name? As pointed out by Chaloner (1986), a much better solution is to merely give them an informal label such as "Lepidodendron plant", which achieves everything that is needed, without the potential disruption to other parts of the palaeobotanical taxonomy (compare similar comments by Crane 1984, Bomfleur et al. 2013).

\section{Naming life-history stages}

ICN, Art. 1.2 also allows different life-history stages to be given separate taxonomic names. Gametophytes of pteridophytic plants are usually too delicate to be preserved as fossils but, where they are found, they have been given separate taxonomic names to the sporophytes: for instance, in the Lower Devonian Rhynie Chert fossil flora, Lyonophyton W.REMY et R.RemY, Kidstonophyton W.RemY et Hass and Langiophyton W.REMY et Hass (Remy and Remy 1980, Remy and Hass 1991a, b) are the gametophytes of the plants with sporophytes Aglaophyton D.S.Edwards, Nothia A.G.Lyon and Horneophyton Bargh. et DARRAH, respectively (Barghoorn and Darrah 1938, Lyon 1964, Edwards 1986; see Kerp et al. 2003 for a review). An example of the taxonomic distinction of different life stages 
of a sporophyte are the saplings of what is often referred to as the "Archaeopteris tree" (Late Devonian trees with Archaeopteris DAwsON leafy shoots and Callixylon ZALESSKY woody stems; Dawson 1871, Zalessky 1911) which are referred to the fossil-genus Eddya C.B.BECK (Beck 1967; Text-fig. 6).

Fossil fungi present particular problems. Living fungi can occur in either their asexual stage (anomorph) or sexual stage (teleomorph), and historically it has often proved difficult to correlate these stages. Consequently, the older nomenclatural codes allowed these stages to be assigned different taxonomic names. More recently, however, molecular studies have enabled some of the different stages to be correlated and the resulting whole organism is known as a holomorph. Since the Melbourne ICN (McNeil et al. 2012) only one name can be given to a living fungus taxon and priority must be given to the first named regardless if its type is an anamorph or teleomorph (Hawksworth 2011, May et al. 2019). However, as fossil fungi will lack molecular data this remains a significant problem for palaeomycology (Taylor et al. 2015).

\section{Recognising living plant taxa in the fossil record}

There is a gradation between today's living vegetation and the extinct vegetation preserved in the fossil record, with a transition represented by historical herbaria and archaeological samples (Collinson 1986). This raises the question, when is it legitimate to use taxa of living plants for plant fossils? Especially with angiosperm remains, plant parts such as leaves may seem indistinguishable from the equivalent parts of extant taxa (Text-fig. 7) but this can be misleading; there have been cases where seeds resembling those of one living genus have been found attached to leafy shoots attributable to another living genus (e.g., Crane 1984). Collinson (1986) has, therefore, argued that it is normally best if extant species and genera are not used for

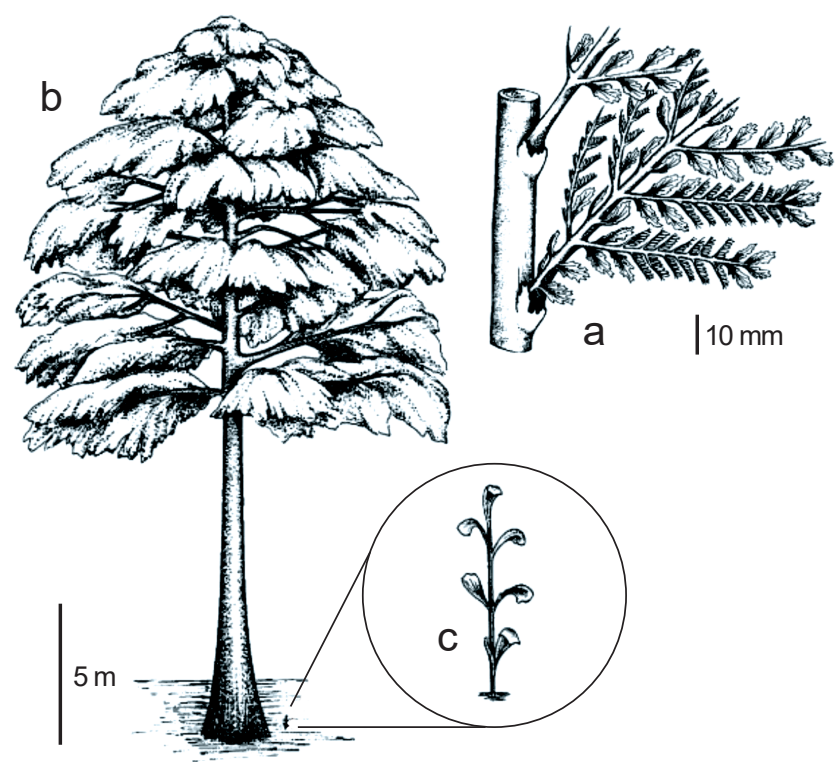

Text-fig. 6. a: Reconstruction of the fertile shoot Archaeopteris from the Late Devonian; b: Reconstruction of tree that bore Archaeopteris shoots; c: Juvenile form ("sapling") of Archaeopteris-bearing tree. Redrawn from Cleal and Thomas (2019). fossil remains. At the time of writing her paper, Collinson pointed out that the Code presented a number of hurdles to developing a practical taxonomy and nomenclature for these fossils, but these have mostly disappeared with the use of fossil-taxa as allowed in the current ICN (Turland et al. 2018). As pointed out by Collinson (1986), however, there remains the problem of the gradation between the fossil record and today's vegetation; it would make little sense to use fossil-taxa for historical herbarium specimens or even archaeological samples, but where should the line be drawn?

The problem is less acute with small, herbaceous plants where whole or near-whole organisms may be preserved. In the Carboniferous floras of the low-palaeolatitudes of Euramerica, there are herbaceous lycopsids that are very similar morphologically to extant species of Selaginella. These fairly rare fossils have usually been placed in the fossil-genus Selaginellites ZeILler (Zeiller 1906) which was intended for Selaginella-like fossils but whose botanical affinities at least at the rank of genus could not be definitely verified (similar to how Schlotheim (1820) and Brongniart $(1822,1828 \mathrm{a})$ used names such as Filicites for fern-like fossils). However, the type of Selaginellites from the upper Carboniferous Blanzy Coalfield in France (S. suissei ZeIller) has a dichotomously branched stem, dimorphic leaves, and a terminal bisporangiate cone with apical microsporangia and basal megasporangia, which is very similar to many living anisophyllous species of Selaginella with tetragonous strobili (e.g., S. vogelii SPRING, S. cathedrifolia Spring, S. pervllei SprIng; see Thomas and Quansah 1991, Quansah and Thomas 2021). Thomas (2005) therefore took the view that it was legitimate to include at least some of the Carboniferous herbaceous lycopsid fossils within the extant genus Seleginella, but assigned to a separate subgenus Hexaphyllum B.A.THомAs: Selaginella gutbieri (Göpr.) B.A.Thомаs (Thomas 2005), Selaginella stachygynandroiodes (GeINITz) B.A.Thomas and Selaginella zeilleri (T.Halle) B.A.Thomas (Thomas 1997).

\section{The effect of different states of preservation}

Art. 1.2 of the ICN (Turland et al. 2018) states that a fossil-taxon can also represent plant remains in a particular preservation state. Different preservation states can yield different types of information about the plant, and a fossilspecies diagnosed on cellular details seen in anatomicallypreserved fossils may be unrecognisable in adpressions; similarly, species diagnosed on morphological characters from adpressions (e.g., frond architecture) may be difficult to recognise in anatomically-preserved fossils.

There are cases where some morphological data can be obtained from anatomically preserved fossils. For instance, Beeler (1983) described coal-balls with anatomically preserved medullosalean pinna fragments where paradermal sections showed the pinnules to be similar in shape and venation to those in the adpression fossil-species Neuropteris ovata Fr.Hoffm. (Hoffmann 1826). In this case the taxonomic assignment seems reasonable as the pinnules were relatively flat and so the paradermal sections provided a reasonable representation of the overall pinnule shape. However, in other medullosaleans such as Alethopteris 

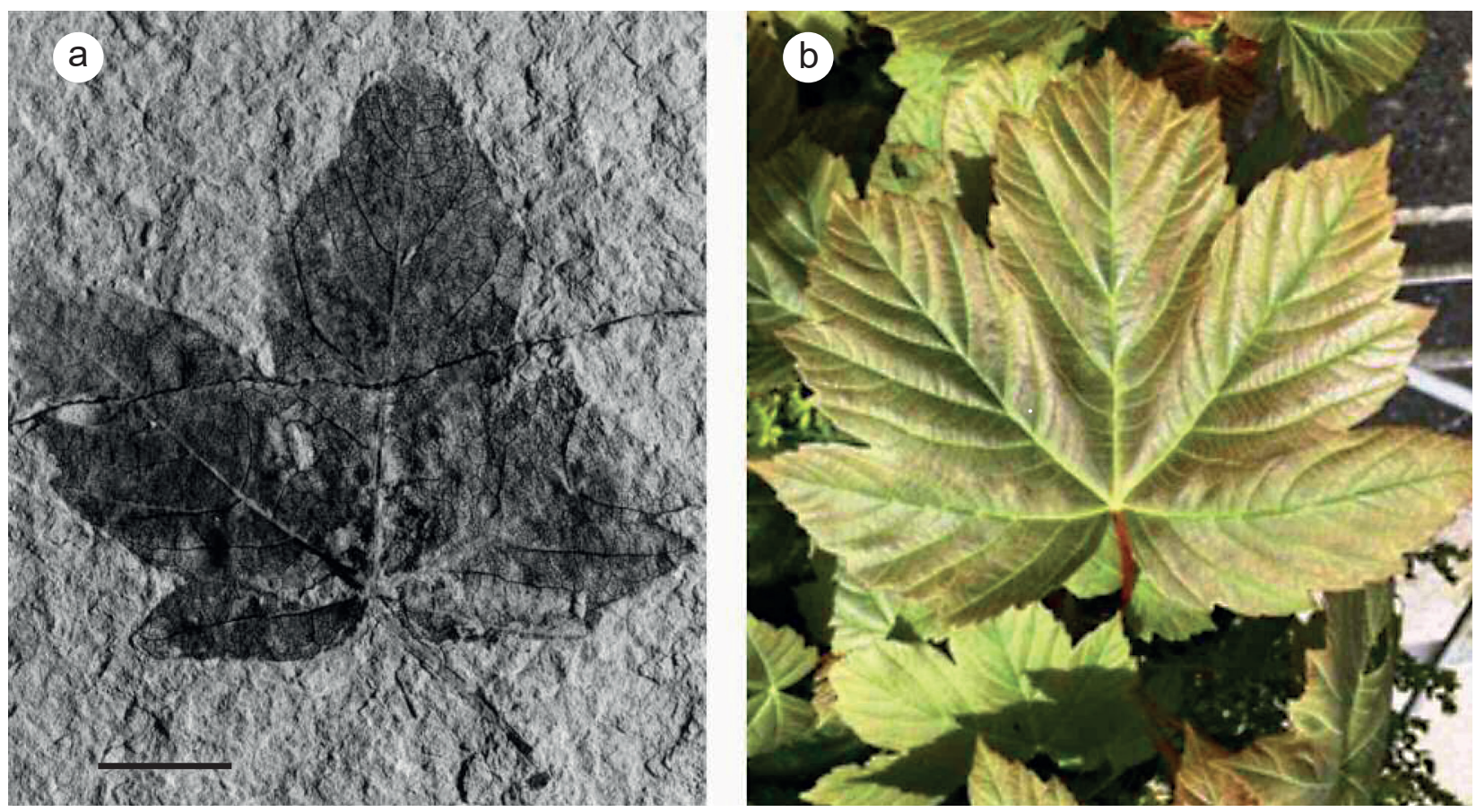

Text-fig. 7. Fossil and living examples of leaves of Acer. a: Acer sp. (fossil), Pleistocene diatomaceous deposits near Faufouille, France (scale bar $=10 \mathrm{~mm}$ ); National Museum Wales specimen 86.54G.1a; b: Leaf from living Acer growing near Machynlleth, mid-Wales, UK; photo by B. A. Thomas.

SternB. (Sternberg 1825) the pinnule limb is significantly vaulted and so paradermal sections do not normally show the pinnule shape so well (Raymond et al. 2013). Moreover, the generic taxonomy of the medullosalean adpression foliage is heavily dependent on frond architecture (Laveine 1967, 1997, Cleal and Shute 1995), which is rarely determinable in the much smaller fossils found in coalballs; for instance, Beeler (1983) found no evidence of the basal dichotomy of the primary rachis, which is a key diagnostic character of $N$. ovata frond adpressions (e.g., Zodrow and Cleal 1988). Either the anatomically preserved fronds were non-dichotomous and borne on different plants to those preserved as adpressions (probably unlikely) or the morphological data provided by the anatomically preserved fossils are incomplete. There are also other adpression taxa similar to $N$. ovata that are distinguished on the shapes of the pinnae and terminal pinnules that would be difficult to see in the coal-ball fossils (Saltzwedel 1969, Cleal and Zodrow 1989). Since, it is impossible to identify reliably all of the characters used to define the taxa distinguished in adpressions in anatomically-preserved fossils, it is best not to use the adpression taxa for coal-ball fossils. In this case, anatomically-preserved medullosalean pinnae are best retained in the fossil-genus Myeloxylon BRONGN. (Brongniart 1849) which was defined on purely histological characters.

There can also be problems with identifying in adpressions the histological features used to define taxa of anatomically preserved fossils. Lepidodendron STERNB. is a well-documented fossil-genus of Palaeozoic arborescent lycopsid stems preserved as adpressions and casts (Crookall 1964, Thomas 1970a, Tenchov 1987, Álvarez-Vázquez and Wagner 2014). However, stems of the same plants have been divided into fossil-genera based on data that can rarely be seen in adpressions (e.g., Diaphorodendron
DiMichele, Synchysidendron DiMichele et Bateman, Hizemodendron Bateman et DiMichele (DiMichele 1985, Bateman and DiMichele 1991, DiMichele and Bateman 1993); for a summary see Bateman et al. 1992). There have been attempts to integrate the classifications for these stems in different preservation states (e.g., Cleal and Wang 2002, DiMichele et al. 2013, Bateman and DiMichele 2021) but Laveine et al. (2003) argued that the morphological characters recognisable on the adpressions were simply not reliable enough guides to distinguishing the fossil-genera based on anatomical criteria; the two sets of fossil-genera are best kept separate (Thomas and Cleal 2020).

This is not to say that fossils in different preservation states must always be assigned to different fossil-taxa; if it is possible to map with reasonable reliability the fossiltaxa between the different types of fossil then it obviously makes sense to use the same taxa (DiMichele and Bateman 2020). For instance, most strobili of Carboniferous sphenopsids are assigned to either Calamostachys Sснім. or Palaeostachya C.E.WeIss based mainly the position of the sporangiophores relative to the bracts, and these characters can be seen in both adpressions and anatomically-preserved floras (Gastaldo 1981, Cleal and Shute 2016). Similarly, the large dichotomising rhizophore bases of the arborescent lycophytes are called Stigmaria BRONGn. in both full-sized or fragmentary casts and anatomically preserved fragments found in coal balls (Williamson 1887, Thomas and Seyfullah 2015b).

However, such unequivocal one-to-one mapping of the taxa between preservation states tends to be rare and, to avoid taxonomic confusion, it is normally advisable to keep separate the fossil-taxa for different preservation states. 


\section{Taxonomic rank}

Palaeobotanical taxonomy uses the same hierarchical structure as the taxonomy of living plants. Fossil-taxa can be of any rank, but the most commonly encountered are fossil-species and fossil-genera. Species of living plants were traditionally defined on distinctive morphological characters, but more recently with the added criteria of reproductive isolation (although the importance of this has been questioned - Rieseberg et al. 2006) and molecular data (e.g., de Vere et al. 2015). Reproductive isolation and molecular data clearly cannot be used with the fossil record and so fossil-species can only be defined on morphological or histological criteria, e.g., the consistent co-occurrences of a particular range of morphotypes. Consequently, although fossil-species are broadly similar in practice to whole plant species in that both are mainly defined by morphological characteristics, there is a fundamental conceptual difference: there is at least the potential for using reproductive and/or molecular evidence in defining whole plant taxa, but this can never be used for the fossil-taxa.

Fossil-species are sometimes divided into taxonomic varieties or even forms. This is usually based on characters that are not always preserved in the fossils: for instance, Cleal and Zodrow (1989) proposed the recognition of varieties of Neuropteris ovata Fr.HofFM. fronds based on epidermal features that can only be recognised if cuticles are preserved.

Fossil-species are grouped into fossil-genera. It would seem logical to try and make fossil-genera agree with the genera of the plants that produced those fossils but this is often not possible. For instance, the Medullosales were trees and woody scrambling plants that occurred widely in late Carboniferous and early Permian wetland floras. All of the plants in this order seem to have had similar distinctive stems with a dissected stele that when anatomically preserved are assigned to the fossil-genus Medullosa CotTA (Cotta 1832; hence the name of the order). This fossil-genus can, therefore, in effect be taken as a proxy for a whole-plant order rather than a genus of whole-plants. In contrast, the large ovules that are assigned to the fossil-genus Pachytesta BRongn. (Brongniart 1874) appear to be restricted to just one of the medullosalean families, the Alethopteridaceae. Hence, fossil- taxa for different parts of the plant can indicate different ranks of whole-plant taxa: in this case, an ovule genus indicates a family whereas the stem genus indicates an order.

This does not make a fossil-genus such as Medullosa artificial, as it clearly correlates with a natural taxon of whole plants - just not a taxon of the same rank as the fossil-taxon. Similarly, foliage adpressions probably yield relatively limited evidence as to their systematic position in terms of families or orders, but their fossil-species and fossil-genera have proved invaluable in floristic and palaeoecological studies (e.g., Cleal et al. 2010). All of these fossil-taxa are natural (in the normal accepted taxonomic sense of natural) as they provide evidence of the systematic position of the parent plants, but not necessarily at the same rank.

For situations where there are discrepancies between the rank of a fossil-taxon and the rank of the plant that produced the fossils, Meyen (1978) introduced the concept of satellite taxa (the term satellite taxon was later used by Hanski (1982) in a quite difference sense in ecological studies). In the above quoted example, Pachytesta would be attributable to the family Alethopteridaceae (order Medullosales) whereas Medullosa would be a satellite-genus of the order Medullosales (Tab. 2). This is perfectly compatible with the ICN as the sequence of taxonomic ranks is not being disturbed; it just means that one or more ranks are omitted when describing the systematic position of a fossil-taxon. An example of the use of satellite taxa was in a classification of lycopsids by Thomas and Brack-Hanes (1984) that attempted to incorporate fossil-genera of stems, rooting structures and even some of the less well-defined fructifications; see also their use in classifying Permian noeggerathioid remains by Gao and Thomas (1987).

The ICN allows for the recognition of fossil-taxa at supra-generic ranks; for instance, Cleal and Shute (2003) proposed a set of fossil-families of medullosalean fronds. More commonly, however, fossil-genera from different plant parts are combined to form what are in essence wholeplant families, although emphasis has often been given to the reproductive organs when defining the circumscription (e.g., Meyen 1984, Thomas and Brack-Hanes 1984, Anderson et al. 2007). Being more like whole-plant taxa was one of the arguments for using families rather than lower-

Table 2. Systematics of selected medullosalean fossil-genera and satellite-genera.

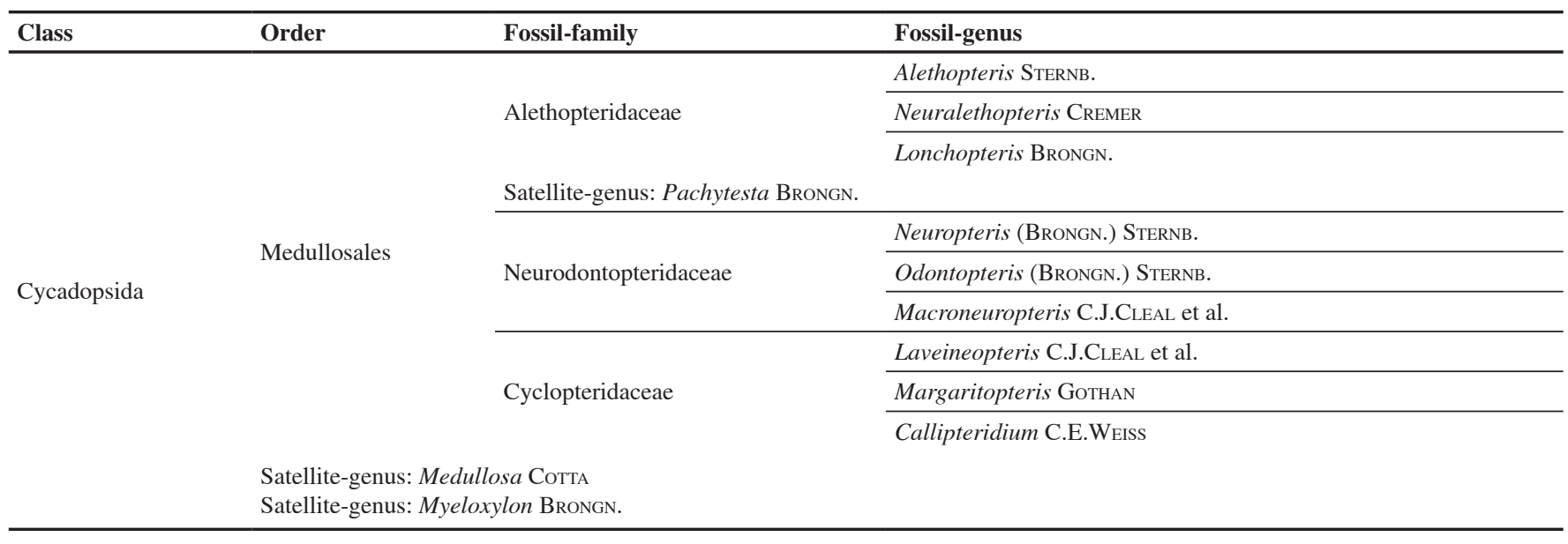


ranked fossil-taxa for investigating large-scale patterns in vegetation history, such as the effects of mass extinctions (e.g., Cascales-Miñana et al. 2013, Cleal and CascalesMiñana 2014).

\section{"Artificial" fossil taxa}

Another distinctive aspect of palaeobotanical taxonomy is that it is possible to have taxa for poorly preserved fossils that cannot be placed in a phylogenetic classification, except perhaps as satellite-taxa of a division or maybe class. Although such "artificial" taxa may be of limited phylogenetic or floristic interest, they have proved useful in palaeoecological studies or even just for curatorial purposes. Jongmans et al. (1935) suggested that the nomenclature of such taxa should not have to follow all of the normallyaccepted rules for botanical nomenclature but this was rejected by most in the palaeobotanical community; some palynologists have also suggested using different taxonomic categories to those covered by the ICN (Hughes 1970, Hughes and Moody-Stuart 1969, Visscher 1971, Van der Zwan 1979) but these have also not been widely adopted. Although the ICN does not prevent the use of such "artificial" taxa, it does place some constraints on how they are defined if nomenclatural stability is to be achieved, in particular on the choice of type. This is best explained using a series of examples.

\section{Hostinella Barrande ex Stur, 1881}

Silurian and Devonian fossil floras regularly yield fragments of slender, dichotomous axes that lack spines, leaves or attached sporangia, but determining their taxonomic affinities is virtually impossible. In stratigraphically younger fossil floras, such remains would normally be dismissed as merely unidentifiable plant debris and would not be named taxonomically. However, they play a more important role in understanding the development of the earliest terrestrial biotas and (following Høeg 1942, 1952) they are often placed in a separate fossil-genus (e.g., Edwards 1979, 1980, Prestianni et al. 2012). The problem is that the generic types are Middle Devonian stems that appear to be parts of early progymnosperm fructifications (Matten and Schweitzer 1982). Since none of Stur's types can really be incorporated within the generic concept as envisioned by Høeg (1942), it is illegitimate to use the name Hostinella in this way.

\section{Psilophytites Høє, 1952}

Høeg (1952) created this fossil-genus to be similar to Hostinella as he had defined it, but for axes with "... spreading undivided spines." Most of the specimens that Høeg listed as typifying the fossil-genus had either not been published with a species name or had been assigned (incorrectly, according to Høeg) to other, better-known species such as Psilophyton princeps Dawson. However, one was the holotype of Psilophyton rectissimum HøЕG (Høeg 1945), which consisted of a spiny axis lacking reproductive structures or anatomy, exactly as Høeg had defined Psilophytites. Since it is unlikely that reproductive structures or cell structure will ever be found for the $P$. rectissimum holotype, it is unlikely to be ever transferred to another, more natural taxon. It therefore makes complete sense also to designate the Høeg (1945) specimen the generic lectotype for Psilophytites, thereby effectively stabilising the name for the fossil-genus envisaged by Høeg (1952).

\section{Pecopteris (Brong.) Sternb., 1825 (三 Filicites (Pecopteris) Brongn., 1822)}

Fern-like frond fragments with small dentate pinnules are common in many Carboniferous and Permian adpression floras. When evidence of reproductive structures has been available, they have been assigned to one of various fossilgenera (e.g., Acitheca Schimp., Cyathocarpus C.E.WeIss and Seftenbergia CoRDA; Corda 1845, Weiss 1869, Schimper 1879) but for many species these structures are unknown (many such species can be found in the monographs by Corsin (1951) and Dalinval (1960)). Traditionally these fossils have been assigned to the fossil-genus Pecopteris, adopting the original diagnosis given by Brongniart (1822), but this overlooks the fact that the reproductive structures of the type of Pecopteris (P. penniformis) are well documented: they compare with the sori of the tedeleacean fern Senftenbergia (Bertrand 1912, Bek and Pšenička 2001, Frojdová et al. 2020).

There are two potential solutions to this problem. The original Brongniart (1822) taxon could be retained (with the change of rank suggested by Sternberg 1825), and all fernlike fossil fronds with small, linguaeform to dentate pinnules assigned to Pecopteris, irrespective of affinities. This has the advantage of inclusivity, as no fossils of this type need be excluded, but has the disadvantage of lacking any taxonomic resolution. Since it is now accepted that at least two distinct orders of ferns (Marattiales and Filicales) have fronds with such dentate pinnules, and they even occur in some seedplants (e.g., Callistophytales - e.g., Crookall 1930), such a lack of resolution would be clearly disadvantageous.

It was for this reason that a more natural classification was developed that takes into account the reproductive structures (summarised by Cleal 2015). But what happens to the species for which the reproductive structures are unknown? It would be possible to create a new fossil-genus for the fossil-species for which reproductive structures are unknown. But for this to be a stable concept, the type would have to be chosen such that reproductive structures would be impossible or unlikely ever to be found - otherwise, as soon as those structures were discovered, the type would be excluded from the fossil-genus and a new name would need to be created. The only real solution is to make comparisons with the framework species of the classification (i.e., those for which sori/synangia are known) based on morphological features of the sterile pinnae, and named maybe using open nomenclature - not a totally satisfactory solution but maybe the only practical one.

\section{Lepidostrobus variabilis LindL. et HutTon emend. by Chaloner (1953)}

Brongniart (1828b) named and briefly described as the holotype of Lepidostrobus a fossilised cone figured by Parkinson (1804). From then on, all cones that even vaguely fitted Brongniart's morphological criteria were included in this genus. Sporophyll morphology later came to be 
regarded as the most important character for taxonomic purposes. Lepidostrobus was generally accepted to be a heterogenous group including both bisporangiate cones with megaspores and microspores, and microsporangiate cones with just microspores.

However, it eventually became obvious that, wherever possible, the in-situ spores in the cones need to be thoroughly investigated for an accurate determination (Chaloner 1953, Felix 1954). The earlier taxonomic efforts emphasized the characteristics of the megaspores rather than those of the microspores. Although microspores from Lepidostrobus can be correlated with the genus Lycospora J.M.SCHOpF, L.R.Wilson et Bentall (Schopf et al. 1944), it is often difficult to relate them to the dispersed spore species. Nevertheless, studies of in-situ spores have suggested that there are at least two groups of Lycospora: those with distinctive proximal ornamentation and broad equatorial flange occur within microsporangiate Lepidostrobus strobili, whilst those with smooth proximal surfaces lacking broad equatorial flanges occur within bisporangiate strobili (Thomas 1970b, 1978, Thomas and Dytko 1980). Since the type of Lepidostrobus contained microspores of the type found in microsporangiate cones, Brack-Hanes and Thomas (1983) redefined Lepidostrobus as a fossil-genus of microsporangiate strobili; bisporangiate cones formerly included in Lepidostrobus were transferred to Flemingites CARruth. (Carruthers 1865).

So, what should the strobili that lack evidence of their spore content be called? They originally tended to be referred to as Lepidostrobus sp. but there was also a tendency to give them specific names based on morphological features. This could imply they were microsporangiate cones, which might not necessarily be correct and could be misleading. Chaloner (1953) suggested that the fossil-species Lepidostrobus variabilis as emended by Arber (1922) should be retained as a designation for such barren cones (the revision of this species by Sen (1958) should probably be rejected as having been based on contaminated samples - Bek 2012). This seems to us as an admirable suggestion and would leave no doubt about it use when applied to figured cones or identifications in species lists.

\section{Taeniopteris BRONGN., 1828a}

Cycad-like fronds are common in Mesozoic fossil floras but it has been recognised since Thomas and Bancroft (1913) that they include both cycadalean and bennettitalean foliage, two groups of seed plants that are only distantly related. The two types of frond can be easily distinguished if cuticles are preserved but is less so in impressions. Some of these foliage genera are sufficiently distinctive morphologically that they can be separated without cuticles, and hence assigned to either the cycads or bennettites; the distinctive Otozamites BRAUN (Braun 1844) fronds, for instance, are generally regarded as bennettitalean (Harris 1969). Other genera are more problematic, however, not least the more or less entire leaves of the Taeniopteris/Nilssonia/Nilssoniopteris complex.

The nomenclatural confusion surrounding the cycadalean Nilssonia Brongn. (Brongniart 1825) and bennettitalean Nilssoniopteris NATH. (Nathors 1909) has been extensively discussed (Cleal and Rees 2003, Cleal et al. 2006, van Konijnenburg-van Cittert et al. 2017, Pott and van Konijnenburg-van Cittert 2017) and need not be repeated here. The lectotype of Taeniopteris as designated by Cleal and Rees (2003: 763) is a very similar shaped leaf but with no cuticle preserved. Since this fossil originated from the Middle Jurassic Stonesfield flora that hardly ever yields cuticles, it will almost certainly be impossible ever to place the Taeniopteris lectotype within the circumscription of either Nilssonia or Nilssoniopteris. To further clarify the situation, Cleal and Rees (2003: 762) emended the diagnosis of the genus containing the type of Taeniopteris so that it can only include species that have not yielded cuticles. By strictly following ICN, therefore, we have ended up with three fossil-genera of essentially similar-shaped entire or near-entire cycadophyte leaves: Nilssonia for those species attributable to the Cycadales, Nilssoniopteris for those attributable to the Bennettitales, and Taeniopteris for the less-well known species unattributable to either group.

\section{Androstrobus Schimper, 1870 emend. by Glasspool et al. in Deng et al. (2014)}

Androstrobus has been widely used for adpressions of Mesozoic cycadalean pollen organs (e.g., Harris 1964, Watson and Cusack 2005). The genus was originally defined through relatively generalised morphological characters but van Konijnenburg-van Cittert (1971) refined the definition using cuticular and pollen characters, and a morphologically similar set of fossil cones was separated off into a second fossil-genus, Hastystrobus van KonIJNENB.

However, Archangelsky and Villar de Seoane (2004) pointed out that the holotype of Androstrobus preserves neither cuticles nor pollen, so it is impossible to confirm if it in fact belongs to either Androstrobus sensu Konijnenburgvan Cittert (1971) or Hastystrobus. Consequently, Deng et al. (2014) proposed that Androstrobus sensu Konijnenburgvan Cittert (1971) should be placed in a new fossil-genus, Schimperostrobus Glasspool, J.Hilton, S.H.Deng et DejaX. Deng et al. (2014) also emended Androstrobus to include only cycad-like microstrobili of this type, but for which pollen or cuticles are unknown. As pointed out in Deng et al. (2014), this limits the use of Androstrobus in phylogenetic studies, but is a useful taxon for recording cones of this type in museum collections and geological studies.

\section{Conclusions}

Palaeobotanical taxonomy would appear to differ conceptually from that used for living plants for the simple fact that it deals with the classification of inanimate objects and not of living organisms. As we have discussed in this paper, the separation is not always so clear-cut in practice because plant fossils are the remains of once living organisms and sometimes have remnant organic tissue such as cuticle or spores in reproductive organs. However, there are things that you can do with taxa of living plants (e.g., examine the complete organism, analyse DNA, fully investigate reproductive biology) that cannot be done with fossils and, for this reason, the two taxonomies have to be regarded as distinct. 
Plant fossils are classified as fossil-taxa that can represent a part or combination of parts of the parent plant in one or more states of preservation, and at one or more stages of its life history, depending on the diagnosis. The circumscription of a fossil-taxon is not constrained by the ICN, which only specifies that the name of such a taxon must be a fossil specimen. This flexibility allows palaeobotanists to make decisions that could lead to taxonomic disruption or instability, but is this any different from the situation in neobotany? It should surely not be the role of the ICN to police palaeobotanists when making taxonomic decisions.

It is obvious that palaeobotanists must have a clear understanding of the diagnoses and circumscriptions of the fossil-taxa they are using because this can significantly affect the information that the taxonomic names are conveying. Although there is normally the aspiration that palaeobotanical taxonomy will at least partly reflect the phylogenetic relationships of the parent plants, the correspondence will rarely if ever be perfect. A fossil-species of foliage, for instance, may have been borne by more than one plant species; and in some cases, a plant species may have different types of leaf that when found isolated would be placed in different fossil-species or even fossil-genera (e.g., Shute and Cleal 2002). The ranks of the taxa may even be different - a fossil-genus may reflect a family or even order of the parent plants. Moreover, for a particular plant group, the fossil-taxa for different plant parts may reflect different taxonomic ranks of the plants: a fossil-genus of seeds may reflect the plant family whereas a fossil-genus of stems of the same plant may only reflect the taxonomic order. Uncritically collating fossil-taxa such as for diversity, biostratigraphical or floristic studies will evidently, therefore, be fraught with danger (see Cleal et al. 2012 for ways of overcoming this problem of taxonomic inflation).

Provided that fossil-taxa are used carefully, the flexibility of this system has many benefits as such taxa will provide an accurate picture of the taphonomically-complex plant fossil record. Nevertheless, this flexibility requires care when fossil-taxa are revised as information improves; for instance, combining fossil-taxa when two or more plant parts are shown in attachment can unwittingly disrupt the wider palaeobotanical taxonomy. Combining fossil-taxa might seem a good idea when working with an unusually well-preserved flora, but in fact delivers relatively little real scientific benefit to improving understanding of that flora and may disrupt the taxonomy being used by many others.

Ultimately, our only direct source of empirical evidence of past vegetation in deep time is the plant fossil record, and our models of phylogenetic and vegetation history have to be grounded in sound palaeobotanical taxonomy. This is particularly important for diversity and floristic studies, where accurate recording of taxonomic distributions is vital. It is critical that palaeobotanists understand exactly what is meant when a fossil-taxon is being recorded and how it is providing a different set of data compared with when a botanist is recording a taxon of living plant.

\section{Acknowledgements}

This paper is based on a presentation made by the authors at a meeting of the Palaeobotany Specialist Group of the
Linnaean Society of London, and they acknowledge the useful discussions with delegates that took place during and after that meeting. In particular, they would like to thank Jason Hilton (Birmingham University) for his valuable insights and for providing the then unpublished data on Androstrobus. We would like acknowledge the eminent English poet Henry Reed (1914-1986) as we have adopted the title of his most famous poem (Naming of parts) for part of the title of our paper.

\section{References}

Allen, K. C. (1961): Lepidostrobophyllum fimbriatum (Kidston 1883) from the Drybrook Sandstone (Lower Carboniferous). - Geological Magazine, 98: 225-229. https://doi.org/10.1017/S0016756800060477

Álvarez-Vázquez, C., Wagner, R. H. (2014): Lycopsida from the lower Westphalian (Middle Pennsylvanian) of the Maritime Provinces, Canada. - Atlantic Geology, 50: 167-232. https://doi.org/10.4138/atlgeol.2014.011

Anderson, J. M., Anderson, H. M., Cleal, C. J. (2007): Brief history of the gymnosperms: classification, biodiversity, phytogeography and ecology. - South Africa National Biodiversity Institute, Pretoria (Strelitzia, 20), 280 pp.

Andrews, H. N. (1980): The fossil hunters. In search of ancient plants. - Cornell University Press, Ithaca, 421 pp.

Arber, E. A. N. (1922): Critical studies of Coal-measure plant-impressions. - Botanical Journal of the Linnean Society, 46: 171-217. https://doi.org/10.1111/j.1095-8339.1922.tb00484.x

Archangelsky, S., Villar de Seoane, L. (2004): Cycadean diversity in the Cretaceous of Patagonia, Argentina. Three new Androstrobus species from the Baqueró Group. Review of Palaeobotany and Palynology, 131: 1-28. https://doi.org/10.1016/j.revpalbo.2004.01.008

Artis, E. T. (1825): Antediluvian phytology, illustrated by a collection of the fossil remains of plants peculiar to the coal formations of Great Britain. - J. Cumberland, Rodwell and Martin, W. Phillips, Taylor, Hessey and Nichols and Son, London, 13 pp. https://doi.org/10.5962/bhl.title.119718

Barghoorn, E. S., Darrah, W. C. (1938): Horneophyton, a necessary change of name for Hornea. - Botanical Museum Leaflets, 6: 142-144. https://doi.org/10.5962/p.168398

Barthel, M. (1968): "Pecopteris" feminaeformis (Schlotheim) Sterzel und "Araucarites" spiciformis Andrae in Germar - Coenopteridee des Stephan und Unteren Perm. - Paläontologische Abhandlungen, B, 2: 727-742.

Barthel, M. (1976): Die Rotliegendflora Sachsens. - Abhandlungen aus dem Staatliches Museum für Mineralogie und Geologie Dresden, 24: 1-190.

Barthel, M. (2015): Die Rotliegendflora der Döhlen-Formation. - Geologica Saxonica, 61: 105-238.

Bateman, R. M., DiMichele, W. A. (1991): Hizemodendron, gen. nov., a pseudoherbaceous segregate of Lepidodendron (Pennsylvanian): Phylogenetic context for evolutionary changes in lycopsid growth and architecture. Systematic Botany, 16: 195-205.

https://doi.org/10.2307/2418983 
Bateman, R. M., DiMichele, W. A. (2021): Escaping the voluntary constraints of "tyre-track" taxonomy. - Taxon, 70(5): 1062-1077.

https://doi.org/10.1002/tax.12540

Bateman, R. M., DiMichele, W. A., Willard, D. A. (1992): Experimental cladistics approach of anatomically preserved arborescent lycopsids from the Carboniferous of Euramerica: An essay on paleobotanical phylogenetics. Annals of the Missouri Botanical Gardens, 79: 500-559. https://doi.org/10.2307/2399752

Bateman, R. M., Hilton, J. (2009): Palaeobotanical systematics for the phylogenetic age: applying organ-species, form-species and phylogenetic species concepts in a framework of reconstructed fossil and extent wholeplants. - Taxon, 58: 1254-1280. https://doi.org/10.1002/tax.584016

Beck, C. B. (1967): Eddya sullivanensis, gen. et sp. nov., a plant of gymnospermic morphology from the Upper Devonian of New York. - Palaeontographica, Abt. B, 121: 1-21.

Beeler, H. E. (1983): Anatomy and frond architecture of Neuropteris ovata and N. scheuchzeri from the Upper Pennsylvanian of the Appalachian Basin. - Canadian Journal of Botany, 61: 2352-2368. https://doi.org/10.1139/b83-259

Bek, J. (2012): A review of the genus Lycospora. - Review of Palaeobotany and Palynology, 174: 122-135. https://doi.org/10.1016/j.revpalbo.2011.12.008

Bek, J. (2018): Paleozoic in situ spores and pollen. Sphenopsids. - Palaeontographica, Abt. B, 298: 1-61. https://doi.org/10.1127/palb/296/2017/1

Bek, J., Pšenička, J. (2001): Senftenbergia plumosa (Artis) emend. and its spores from the Carboniferous of the Kladno and Pilsen Basins, Bohemian Massif, and some related and synonymous taxa. - Review of Palaeobotany and Palynology, 116: 213-232. https://doi.org/10.1016/S0034-6667(01)00091-4

Bengtson, P. (1988): Open nomenclature. - Palaeontology, 31: 223-227.

Bengtson, S. (1985): Taxonomy of disarticulated fossils. Journal of Paleontology, 59: 1350-1358.

Bertrand, P. (1912): Note sur un échantilon fructifié des Pecopteris pennaeformis du terrain houiller d'Anzin. Annales de la Société géologique du Nord, 41: 222-233.

Binney, E. W. (1871): Observations on the structure of fossil plants found in the Carboniferous strata. Part II. Lepidostrobus and some allied cones. - Palaeontographical Society Monographs, 24(106): 33-62. https://doi.org/10.1080/02693445.1871.12088361

Bomfleur, B., Decombeix, A. L., Escapa, I. H., Schwendemann, A. B., Axsmith, B. (2013): Whole-plant concept and environment reconstruction of a Telemachus conifer (Voltziales) from the Triassic of Antarctica. - International Journal of Plant Sciences, 174: 425-444. https://doi.org/10.1086/668686

Boulter, M. C. (1968): A species of compressed lycopod sporophyll from the Upper Coal Measures of Somerset. - Palaeontology, 11: 445-457.

Brack-Hanes, S. D., Thomas, B. A. (1983): A re-examination of Lepidostrobus Brongniart. - Botanical Journal of the Linnean Society, 86: 125-133.

https://doi.org/10.1111/j.1095-8339.1983.tb00720.x
Braun, C. F. W. (1844): Beiträge zur Urgeschichte der Pflanzen. - In: Münster, G. (ed.), Beiträge zur Petrefaktenkunde, sechstes Heft. Buchner, Bayreuth, pp. 1-46.

Briquet, J. (1906): Règles internationales de la nomenclature botanique adoptées par le Congrès International de Botanique de Vienne 1905. - Fischer, Jena, 99 pp.

Brongniart, A. (1822): Sur la classification et la distribution des végétaux fossiles en général, et sur ceux des terrains de sediment supérieur en particulier. - Mémoires du Museum d'Histoire Naturelle, Paris, 8: 203-240, 297-348.

Brongniart, A. (1825): Observations sur les végétaux fossiles renfermé dans les Grès de Hoer en Scanie. - Annales des Sciences Naturelles, 4: 200-219.

Brongniart, A. (1828a): Prodrome d'une Histoire des végétaux fossiles. - F. G. Levrault, Paris, Strasbourg, 223 pp. https://doi.org/10.5962/bhl.title.62840

Brongniart, A. (1828b): Histoire des végétaux fossiles, 1(12). - G. Dufour et E. d'Ocagne, Paris, pp. 1-136. https://doi.org/10.5962/bhl.title.60992

Brongniart, A. (1849): Tableau des genres de végétaux fossiles considérés sous le point de vue de leur classification botanique et de leur distribution géologique (Dictionnaire universel d'Histoire Naturelle, 13). - L. Martinet, Paris, 127 pp.

Brongniart, A. (1874): Études sur les graines fossiles trouvées à l'état silicifié dans le terrain houiller de SaintÉtienne. - Comptes rendus hebdomadaires des séances de l'Académie des Sciences, Paris, 79: 427-435.

Candolle, A. de (1867): Lois de la Nomenclature Botanique adoptées par le Congrès International de Botanique tenu à Paris en août 1867 suivies d'une deuxième édition de l'introduction historique et du commentaire qui accompagnaient la rédaction préparatoire présentée au Congrès. - H. Georg, Geneva and Basle, J.-B. Baillière, Paris, 64 pp.

Carruthers, W. (1865): On an undescribed cone from the Carboniferous beds of Airdrie. Lanarkshire. - Geological Magazine, 2: 433-440.

https://doi.org/10.1017/S0016756800162168

Carruthers, W. (1870): On fossil cycadean stems from the Secondary rocks of Britain. - Transactions of the Linnean Society of London, 26: 675-708. https://doi.org/10.1111/j.1096-3642.1870.tb00201.x

Cascales-Miñana, B., Cleal, C. J., Diez, J. B. (2013): What is the best way to measure extinction? A reflection from the palaeobotanical record. - Earth-Science Reviews, 124: $126-147$. https://doi.org/10.1016/j.earscirev.2013.05.013

Chaloner, W. G. (1953): On the megaspores of four species of Lepidostrobus. - Annals of Botany, New Series, 17: 263-293. https://doi.org/10.1093/oxfordjournals.aob.a083350

Chaloner, W. G. (1986): Reassembling the whole fossil plant, and naming it. - In: Spicer, R. A., Thomas, B. A. (eds), Systematic and taxonomic approaches in palaeobotany (Special Volume 31). Systematics Association, London, pp. 67-78.

Chaloner, W. G. (1999): Taxonomic and nomenclatural alternatives. - In: Jones, T. P., Rowe, N. P. (eds), Fossil plants and spores. Modern techniques. Geological Society, London, pp. 179-183. 
Chaloner, W. G., Greuter, W., Nicolson, D. H., Traverse, A. (1998): Proposals regarding the nomenclature of fossil plants. - Taxon, 47: 907-910. https://doi.org/10.2307/1224206

Cleal, C. J. (1986): Identifying plant fragments. - In: Spicer, R. A., Thomas, B. A. (eds), Systematic and taxonomic approaches in palaeobotany (Special Volume 31). Systematics Association, London, pp. 53-65.

Cleal, C. J. (2015): The generic taxonomy of Pennsylvanian age marattialean fern frond adpressions. - Palaeontographica, Abt. B, 292: 1-21. https://doi.org/10.1127/palb/292/2015/1

Cleal, C. J., Cascales-Miñana, B. (2014): Composition and dynamics of the great Phanerozoic Evolutionary Floras. - Lethaia, 47: 469-484. https://doi.org/10.1111/let.12070

Cleal, C. J., Opluštil, S., Thomas, B. A., Tenchov, Y. (2010): Late Moscovian terrestrial biotas and palaeoenvironments of Variscan Euramerica. - Netherlands Journal of Geosciences, 88: 181-278. https://doi.org/10.1017/S0016774600000846

Cleal, C. J., Pardoe, H. S., Berry, C. M., Cascales-Miñana, B., Davis, B. A. S., Diez, J. B., Filipova-Marinova, M. V., Giesecke, T., Hilton, J., Ivanov, D. A., Kustatscher, E., Leroy, S. A. G., McElwain, J. C., Opluštil, S., Popa, M. E., Seyfullah, L. J., Stolle, E., Thomas, B. A., Uhl, D. (2021): Plant diversity in deep time: experiences from the fossil record. I: How well can we distinguish past plant diversity from the fossil record? - Palaeogeography, Palaeoclimatology, Palaeoecology, 576: 110481 (20 pp.). https://doi.org/10.1016/j.palaeo.2021.110481

Cleal, C. J., Rees, P. M. (2003): The Middle Jurassic flora from Stonesfield, Oxfordshire, UK. - Palaeontology, 46: 739-801. https://doi.org/10.1111/1475-4983.00319

Cleal, C. J., Rees, P. M., Zijlstra, G., Cantrill, D. J. (2006): A clarification of the type of Nilssoniopteris Nathorst (fossil Gymnospermophyta, Bennettitales). - Taxon, 55: 219-222. https://doi.org/10.2307/25065546

Cleal, C. J., Shute, C. H. (1995): A synopsis of neuropteroid foliage from the Carboniferous and Lower Permian of Europe. - Bulletin of the British Museum (Natural History), Geology Series, 51: 1-52.

Cleal, C. J., Shute, C. H. (2003): Systematics of the Late Carboniferous medullosalean pteridosperm Laveineopteris and its associated Cyclopteris leaves. - Palaeontology, 46: 353-411.

https://doi.org/10.1111/1475-4983.00303

Cleal, C. J., Shute, C. H. (2012): The systematic and palaeoecological value of foliage anatomy in Late Palaeozoic medullosalean seed-plants. - Journal of Systematic Palaeontology, 10: 765-800. https://doi.org/10.1080/14772019.2011.634442

Cleal, C. J., Shute, C. H. (2016): A new late Carboniferous calamitacean sphenophytefrom South Wales, UnitedKingdom. - Spanish Journal of Palaeontology, 31: 25-40. https://doi.org/10.7203/sjp.31.1.17138

Cleal, C. J., Shute, C. H., Zodrow, E. L. (1990): A revised taxonomy for Palaeozoic neuropterid foliage. - Taxon, 39: 486-492.

https://doi.org/10.2307/1223109
Cleal, C. J., Thomas, B. A. (2010a): Botanical nomenclature and plant fossils. - Taxon, 59: 261-268. https://doi.org/10.1002/tax.591024

Cleal, C. J., Thomas, B. A. (2010b): Proposals to modify the provisions in the Code for naming plant fossils. - Taxon, 59: $312-313$. https://doi.org/10.1002/tax.591051

Cleal, C. J., Thomas, B. A. (2018): Nomenclatural status of the Palaeobotanical "Artificial Taxa" established in Brongniart's 1822 "Classification” paper. - Fossil Imprint, 74: 9-28. https://doi.org/10.2478/if-2018-0001

Cleal, C. J., Thomas, B. A. (2019): Introduction to plant fossils (second edition). - Cambridge University Press, Cambridge, 246 pp. https://doi.org/10.1017/9781108650021

Cleal, C. J., Uhl, D., Cascales-Miñana, B., Thomas, B. A., Bashforth, A. R., King, S. C., Zodrow, E. L. (2012): Plant biodiversity changes in Carboniferous tropical wetlands. - Earth-Science Reviews, 114: 124-155. https://doi.org/10.1016/j.earscirev.2012.05.004

Cleal, C. J., Wang Ziqiang (2002): A new and diverse plant fossil assemblage from the upper Westphalian Benxi Formation, Shanxi, China, and its palaeofloristic significance. - Geological Magazine, 139: 107-130. https://doi.org/10.1017/S0016756801006240

Cleal, C. J., Zodrow, E. L. (1989): Epidermal structure of some medullosan Neuropteris foliage from the middle and upper Carboniferous of Canada and Germany. Palaeontology, 32: 837-882.

Collinson, M. E. (1980): Recent and Tertiary seeds of the Nymphaeaceae sensu lato with a revision of Brasenia ovula (Brong.) Reid and Chandler. - Annals of Botany, New Series, 46: 603-632. https://doi.org/10.1093/oxfordjournals.aob.a085958

Collinson, M. E. (1983): Fossil plants of the London Clay. Palaeontological Association, London, $121 \mathrm{pp}$.

Collinson, M. E. (1986): Use of modern generic names for plant fossils. - In: Spicer, R. A., Thomas, B. A. (eds), Systematic and taxonomic approaches in palaeobotany (Special Volume 31). Systematics Association, London, pp. 91-104.

Corda, A. J. (1845): Beiträge zur Flora der Vorwelt. - J.G. Calve'sche Buchhhandlung, Friedrich Tempsky, Prag, 128 pp. https://doi.org/10.5962/bhl.title. 141710

Corsin, P. (1951): Bassin houiller de la Sarre et de la Lorraine. I. Flore fossile. 4me Fascicule Pécoptéridées. - Études des Gîtes Minéraux de la France, 1: 175-370.

Cotta, C. B. (1832): Die Dendrolithen in Beziehung auf ihren inneren Bau. - Arnold, Dresden and Leipzig, 89 pp.

Crane, P. R. (1984): A re-evaluation of Cercidiphyllum-like plant fossils from the British early Tertiary. - Botanical Journal of the Linnean Society, 89: 199-230. https://doi.org/10.1111/j.1095-8339.1984.tb02196.x

Crookall, R. (1930): Crossotheca and Lyginopteris oldhamia. - Annals of Botany, New Series, 44: 621-637. https://doi.org/10.1093/oxfordjournals.aob.a090240

Crookall, R. (1964): Fossil plants of the Carboniferous rocks of Great Britain [Second Section]. Part 3. - Memoirs of the Geological Survey of Great Britain, Palaeontology, 4: 217-354. 
Crookall, R. (1969): Fossil plants of the Carboniferous rocks of Great Britain [Second Section]. Part 5. - Memoirs of the Geological Survey of Great Britain, Palaeontology, 4: 573-792.

Dalinval, A. (1960): Contribution à l'étude des Pécoptéridées. Les Pecopteris du bassin houiller du Nord de la France. - Études Géologiques pour l'Atlas Topographie Souterraine, 1(3): 1-222.

Dawson J. W. (1871): On new tree-ferns and other fossils from the Devonian. - Quarterly Journal of the Geological Society of London, 27: 269-275. https://doi.org/10.1144/GSL.JGS.1871.027.01-02.38

Deng Shenghui, Hilton, J., Glasspool, I. J., Dejaxc, J. (2014): Pollen cones and associated leaves from the Lower Cretaceous of China and a re-evaluation of Mesozoic male cycad cones. - Journal of Systematic Palaeontology, 12: 1001-1023. https://doi.org/10.1080/14772019.2013.819817

DiMichele, W. A. (1985): Diaphorodendron gen. nov., a segregate from Lepidodendron (Pennsylvanian Age). Systematic Botany, 10: 453-458. https://doi.org/10.2307/2419138

DiMichele, W. A., Bateman, R. M. (1993): Validation of Synchysidendron, gen. nov. (Fossiles). - Taxon, 42: 647-648. https://doi.org/10.2307/1222543

DiMichele, W. A. Bateman, R. M. (2020): Better together: Joint consideration of anatomy and morphology illuminates the architecture and life history of the Carboniferous arborescent lycopsid Paralycopodites. - Journal of Systematics and Evolution, 58: 783-804.

https://doi.org/10.1111/jse.12662

DiMichele,W. A., Elrick, S. D., Bateman, R. M. (2013): Growth habit of the late Paleozoic rhizomorphic treelycopsid family Diaphorodendraceae: Phylogenetic, evolutionary, and paleoecological significance. - American Journal of Botany, 100: 1604-1625. https://doi.org/10.3732/ajb.1200623

DiMichele, W. A., Gastaldo, R. A. (2008): Plant paleoecology in deep time. - Annals of the Missouri Botanical Garden, 95: 144-198. https://doi.org/10.3417/2007016

Edwards, D[avid] S. (1986): Aglaophyton major, a non-vascular land-plant from the Devonian Rhynie Chert. Botanical Journal of the Linnean Society, 93: 173-204. https://doi.org/10.1111/j.1095-8339.1986.tb01020.x

Edwards, D[ianne] (1979): The early history of vascular plants based on late Silurian and early Devonian floras of the British Isles. - In: Harris, A. L, Herdman, J., Holland, C. H., Leake, B. E. (eds), The Caledonides of the British Isles-reviewed. Special Publication, Geological Society, London, 8: 405-410.

https://doi.org/10.1144/GSL.SP.1979.008.01.46

Edwards, D[ianne] (1980): Studies on lower Devonian petrifactions from Britain. 1. Pyritised axes of Hostinella from the Brecon Beacons Quarry, Powys, South Wales. Review of Palaeobotany and Palynology, 29: 189-200. https://doi.org/10.1016/0034-6667(80)90058-5

Felix, C. J. (1954): Some American lycopod fructifications. Annals of the Missouri Botanical Garden, 41: 351-394. https://doi.org/10.2307/2394684
Forey, P. L., Fortey, R. A., Kenrick, P., Smith, A. B. (2004): Taxonomy and fossils: A critical appraisal. - Philosophical Transactions of the Royal Society, Biological Sciences, 359: 639-653.

https://doi.org/10.1098/rstb.2003.1453

Frojdová, J. V., Cleal, C. J., Bek, J., Pšenička, J. (2020): Revision of the Pennsylvanian fern Myriotheca anglica Kidston from the Central Pennine Basin (UK) and its transfer to the genus Pecopteris (Brongniart) Sternberg. - Review of Palaeobotany and Palynology, 279: 104241 (11 pp.). https://doi.org/10.1016/j.revpalbo.2020.104241

Gao Zhifeng, Thomas, B. A. (1987): A re-evaluation of the plants Tingia and Tingiostachya from the Permian of Taiyuan, China. - Palaeontology, 30: 815-828.

Gastaldo, R. A. (1981): Taxonomic considerations for Carboniferous coalified compression equisetalean strobili. American Journal of Botany, 68: 1319-1324. https://doi.org/10.1002/j.1537-2197.1981.tb07842.x

Germar, E. F. (1845): Die Versteinerungen des Steinkohlengebirges von Wettin und Löbejün im Saalkreise, bildlich dargestellt und beschrieben (2). - C. A. Schwetschke und Sohn, Halle, pp. 13-28. https://doi.org/10.5962/bhl.title. 169070

Gothan, W. (1941): Paläobotanische Mitteilungen. 5. Die Unterteilung der karbonischen Neuropteriden. - Paläontologische Zeitschrift, 22: 421-438. https://doi.org/10.1007/BF03042701

Gothan, W. (1953): Die Steinkohlenflora der westlichen paralischen Carbonreviere Deutschlands. Lieferung 5. Geologisches Jahrbuch, Beiheft 10: 1-83.

Gravendyck, J., Fensome, R. A., Head, M. J., Herendeen, P. S., Riding, J. B., Bachelier, J. B., Turland, N. J. (2021): Taxonomy and nomenclature in palaeopalynology: basic principles, current challenges and future perspectives. Palynology, 45(4): 717-743.

https://doi.org/10.1080/01916122.2021.1918279

Habgood, K. S., Hemsley, A. R., Thomas, B. A. (1998): Modelling of the dispersal of Lepidocarpon based on experiments using reconstructions. - Review of Palaeobotany and Palynology, 102: 101-114. https://doi.org/10.1016/S0034-6667(98)00012-8

Hanski, I. (1982): Dynamics of regional distribution: the core and satellite species hypothesis. - Oikos, 38: 210-221. https://doi.org/10.2307/3544021

Harris, T. M. (1964): The Yorkshire Jurassic flora. II. Caytoniales, Cycadales, pteridosperms. - British Museum (Natural History), London, $191 \mathrm{pp}$.

Harris, T. M. (1969): The Yorkshire Jurassic flora. III. Bennettitales. - British Museum (Natural History), London, $186 \mathrm{pp}$.

Hawksworth, D. L. (2011): A new dawn for the naming of fungi: Impacts of decisions made in Melbourne in July 2011 on the future publication and regulation of fungal names. - MycoKeys, 1: 7-20. https://doi.org/10.3897/mycokeys.1.2062

Hirmer, M. (1927): Handbuch der Paläobotanik. Bd. 1. R. Oldenbourg, München, Berlin, 708 pp.

Høeg, O. A. (1942): The Downtonian and Devonian flora of Spitsbergen (Norges Svalbard- og Ishavs-unders kelser, 83). - Oslo University, Oslo, 228 pp. 
Høeg, O. A. (1945): Contributions to the Devonian flora of western Norway. III. - Norsk Geologisk Tidsskrift, 25: 183-192.

Høeg, O. A. (1952): Psilophytites, a new form genus of Devonian plants. - The Palaeobotanist, 1: 212-214.

Hoffmann, F. (1826): Untersuchungen über die PflanzenReste des Kohlengebirges von Ibbenbühren und vom Piesberge bei Osnabrück. - Archiv für Bergbau und Hüttenwesen, 13: 266-282.

Hoskins, J., Cross, A. (1943): Monograph of the Paleozoic Cone Genus Bowmanites (Sphenophyllales). - The American Midland Naturalist, 30: 113-163. https://doi.org/10.2307/2421267

Hughes, N. F. (1970): The need for agreed standards of recording in palaeopalynology and palaeobotany. Paläontologische Abhandlungen, B, 3: 357-364.

Hughes, N. F., Moody-Stuart, J. C. (1969): A method of stratigraphic correlation using early Cretaceous miospores. - Palaeontology, 12: 84-111.

Huxley, J. (1942): Evolution. The modern synthesis. George, Allen \& Unwin, London, 645 pp.

Jones, T. P., Rowe, N. P. (eds) (1999): Fossil plants and spores. Modern techniques. - Geological Society, London, 396 pp.

Jongmans, W. J. (1911): Anleitung zur Bestimmung der Karbonpflanzen West-Europas mit besonderer Berücksichtigung der in den Niederlanden und den benachbarten Länderen gefundenen oder noch zu erwartenden Arten. I Band. Thallophytae, Equisetales, Sphenophyllales. Mededeelingen van de Rijksopsporing van Delfstoffen, 3: $1-482$.

https://doi.org/10.5962/bhl.title.83723

Jongmans, W. J., Halle, T. G., Gothan, W. (1935): Proposed additions to the International Rules of Botanical Nomenclature adopted by the fifth International Botanical Congress Cambridge 1930. - The Authors, Heerlen, 15 pp.

Kendig, C., Witteveen, J. (2020): The history and philosophy of taxonomy as an information science. - History and Philosophy of the Life Sciences, 42: 40 (9 pp). https://doi.org/10.1007/s40656-020-00337-8

Kerp, J. H. F., Haubold, H. (1988a): Towards a reclassification of the West- and Central-European species of the form-genus Callipteris Brongniart 1849. - Zeitschrift für geologische Wissenschaften, 16: 865-876.

Kerp, J. H. F., Haubold, H. (1988b): Aspects of Permian palaeobotany and palynology. VIII. On the reclassification of the West- and Central European species of the formgenus Callipteris Brongniart 1849. - Review of Palaeobotany and Palynology, 54: 135-150.

https://doi.org/10.1016/0034-6667(88)90009-7

Kerp, H., Trewin, N. H., Hass, H. (2003): New gametophytes from the Early Devonian Rhynie chert. - Earth and Environmental Science Transactions of the Royal Society of Edinburgh, 94: 411-428. https://doi.org/10.1017/S026359330000078X

Kidston, R. (1884): On the fructification of Zeilleria (Sphenopteris) delicatula, Sternb., sp.; with remarks on Urnatopteris (Sphenopteris) tenella, Brongt., and Hymenophyllites (Sphenopteris) quadridactylites, Gutbier, sp. Quarterly Journal of the Geological Society, 40: 590-598. https://doi.org/10.1144/GSL.JGS.1884.40.01-04.49 van Konijnenburg-van Cittert, J. H. A. (1971): In situ gymnosperm pollen from the Middle Jurassic of Yorkshire. Acta Botanica Neerlandica, 20: 1-96.

https://doi.org/10.1111/j.1438-8677.1971.tb00688.x

van Konijnenburg-van Cittert, J. H. A., Pott, C., Cleal, C. J., Zijlstra, G. (2017): Differentiation of the fossil leaves assigned to Taeniopteris, Nilssoniopteris and Nilssonia with a comparison to similar genera. - Review of Palaeobotany and Palynology, 237: 100-106. https://doi.org/10.1016/j.revpalbo.2016.11.009

Krasser, F. (1919): Studiën über die fertile Region der Cycadophyten aus dem Lunzer Schichten: Makrosporophylle. - Denkschriften der Kaiserlichen Akademie der Wissenschaften, Mathematisch-Naturwissenschaftliche Classe, 97: 1-32.

Kvaček, Z. (1982): Against the newly proposed starting point in paleobotany. - Taxon, 31: 319 . https://doi.org/10.2307/1219999

Kvaček, Z. (2008): Whole-plant reconstructions in fossil angiosperm research. - International Journal of Plant Sciences, 169: 918-927. https://doi.org/10.1086/589694

Lanjouw, J., Baehni, C., Merrill, E. D., Rickett, H. W., Robyns, W., Sprague, T. A., Stafleu, F. A. (1952): International Code of Botanical Nomenclature: Adopted by the Seventh International Botanical Congress; Stockholm, July 1950 (Regnum Vegetabile 3). - International Bureau for Plant Taxonomy of the International Association for Plant Taxonomy, Utrecht, $228 \mathrm{pp}$.

Laveine, J.-P. (1967): Contribution a l'étude de la flore du terrain houiller. Les Neuroptéridées du Nord de la France. - Études Géologiques pour l'Atlas Topographie Souterraine, 1(5): 1-344.

Laveine, J.-P. (1997): Synthetic analysis of the neuropterids. Their interest for the decipherment of Carboniferous palaeogeography. - Review of Palaeobotany and Palynology, 95: 155-189. https://doi.org/10.1016/S0034-6667(96)00033-4

Laveine, J.-P. (2005): The Cyclopteris of Laveineopteris (Late Carboniferous pteridosperm). Fancies and facts: methodological and taxonomical implications. - Revue de Paléobiologie, 24: 403-487.

Laveine, J.-P., Zhang Shanzhen, Liu Luijun, Gu Fengbau, Liu Yongan, Wen Jinguo, Lemoigne, Y. (2003): The Late Carboniferous floras of the Delingha area (Wulan County, Qinghai Province, Northwest China). - Revue Paléobiologie, 22: 567-651.

Lele, K. M., Walton, J. (1961): Contributions to the knowledge of Zosterophyllum myretonianum Penhallow from the Lower Old Red Sandstone of Angus. - Transactions of the Royal Society of Edinburgh, 64: 469-475. https://doi.org/10.1017/S0080456800100432

Lhuyd, E. (1699): Lithophylacii Britannici ichnographia. Ex officina M. C., London and Sumt. Joh. Ludw. Gleditsch \& Weidmann, Leipzig, 150 pp.

Libertín, M., Bek, J., Drábková, J. (2014): New sphenophyllaleans from the Pennsylvanian of the Czech Republic. - Review of Palaeobotany and Palynology, 200: 196-210.

https://doi.org/10.1016/j.revpalbo.2013.09.008 
Lindley, J., Hutton, W. (1832): The fossil flora of Great Britain. Volume 1 (Part 2). - W. J. Ridgeway and Sons, London, $118 \mathrm{pp}$.

https://doi.org/10.5962/bhl.title.102097

Lindley, J., Hutton, W. (1835): The fossil flora of Great Britain. Volume 3 (Part 1). - W. J. Ridgeway and Sons, London, $72 \mathrm{pp}$. https://doi.org/10.5962/bhl.title.102097

Liu Li, Pšenička, J., Bek, J., Wan Mingli, Pfefferkorn, H. W., Wang Jun (2021): A whole calamitacean plant Palaeostachya guanglongii from the Asselian (Permian) Taiyuan Formation in the Wuda Coalfield, Inner Mongolia, China. - Review of Palaeobotany and Palynology, 294: 104245 (21 pp.).

https://doi.org/10.1016/j.revpalbo.2020.104245

Lyon, A. G. (1964): The probable fertile region of Asteroxylon mackiei K. and L. - Nature, 203: 1082-1083. https://doi.org/10.1038/2031082b0

Malécot, V. (2008): Les règles de nomenclature-Histoire et fonctionnement. - Biosystema, 25: 41-76.

Matthews, S. C. (1973): Notes on open nomenclature and on synonymy lists. - Palaeontology, 16: 713-719.

May, T. W., Redhead, S. A., Bensch, K., Hawksworth, D. L., Lendemer, J., Lombard, L., Turland, N. J. (2019): Chapter $\mathrm{F}$ of the International Code of Nomenclature for algae, fungi, and plants as approved by the 11th International Mycological Congress, San Juan, Puerto Rico, July 2018. - IMA Fungus, 10: 21 (14 pp.). https://doi.org/10.1186/s43008-019-0019-1

McNeill, J., Barrie, F. R., Buck, W. R., Demoulin, V., Greuter, W., Hawksworth, D. L., Herendeen, P. S., Knapp, S., Marhold, K., Prado, J., Prudhomme van Reine, W. F., Smith, G. F., Wierseme, J. H., Turland, N. J. (2012): International Code of Nomenclature for Algae, Fungi, and Plants (Melbourne Code) (Regnum Vegetabile 154). Koeltz Botanical Books, Glashütten, 208 pp.

Meyen, S. V. (1978): Sistematika, filogeniya i ekologiya propteridofitov [Systematics, phylogeny and ecology of propteridophytes]. - Byulleten' Moskovskogo Obshchestva Ispytateley Prirody, Otdel Biologicheskiy, 83(4): 72-84. (in Russian)

Meyen, S. V. (1984): Basic features of gymnosperm systematics and phylogeny as evidenced by the fossil record. - Botanical Review, 50: 1-111. https://doi.org/10.1007/BF02874305

Meyen, S. V. (1987): Fundamentals of palaeobotany. - Chapman and Hall, London, 432 pp. https://doi.org/10.1007/978-94-009-3151-0

Morris, J. E. (1840): Plants from the sandstone and clay, with beds of coal; and shells from the Upper Secondary Formation. - In: Grant, C. W., Memoir to illustrate a geological map of Cutch. Transactions of the Geological Society London, Series 2, 5: Plate 21 (explanation). https://doi.org/10.1144/transgslb.5.2.289

Morris, J. E. (1841): Remarks upon the Recent and fossil Cycadeae. - Annals and Magazine of Natural History, 7: 110-120.

Nathorst, A. G. (1909): Über die Gattung Nilssonia Brongn. mit besondrer Berücksichtigung schwedischer Arten. Kunglinga Svenska Vetenskapsakademiens Handlinga, 43(12): $1-40$.
Olivares, J. (2011): A taxonomy of office chairs. - Phaidon Press, New York, 240 pp.

Parkinson, J. (1804): Organic remains of a former world, 1. - Sherwood and Co, London, $461 \mathrm{pp}$.

Pfefferkorn, H. W., Wang Jun (2016): Paleoecology of Noeggerathiales, an enigmatic, extinct plant group of Carboniferous and Permian times. - Palaeogeography, Palaeoclimatology, Palaeoecology, 448: 141-150.

https://doi.org/10.1016/j.palaeo.2015.11.022

Pott, C., van Konijnenburg-van Cittert, J. H. (2017): The type specimen of Nilssoniopteris solitaria (Phillips 1829) (Bennettitales). - Acta Palaeobotanica, 57: 177-184. https://doi.org/10.1515/acpa-2017-0008

Prestianni, C., Meyer-Berthaud, B., Blanchard, R., Rücklin, M., Clément, G., Gerrienne, P. (2012): The Middle Devonian plant assemblage from Dechra Aït Abdallah (Central Morocco) revisited. - Review of Palaeobotany and Palynology, 179: 44-55.

https://doi.org/10.1016/j.revpalbo.2012.03.011

Pšenička, J., Wang Jun, Bek, J., Pfefferkorn, H. W., Opluštil, S., Zhou Weiming, Frojdová, J. V., Libertín, M. (2021): A zygopterid fern with fertile and vegetative parts in anatomical and compression preservation from the earliest Permian of Inner Mongolia, China. - Review of Palaeobotany and Palynology, 294: 104382 (33 pp.). https://doi.org/10.1016/j.revpalbo.2021.104382

Quansah, N., Thomas, B. A. (2021): Anisophyllous species of Selaginella in West Africa. - The Fern Gazette, 21: 188-238.

Raymond, A. E., Slone, E. D. J., Wehner, M. (2013): A new permineralized Alethopteris from the Kalo Formation and a simple method for distinguishing permineralized Alethopteris species. - New Mexico Museum of Natural History and Science Bulletin, 60: 338-342.

Reid, E. M., Chandler, M. E. J. (1933): The London Clay flora. - British Museum (Natural History), London, 561 pp. https://doi.org/10.5962/bhl.title.110147

Remy, W., Hass, H. (1991a): Kidstonophyton discoides nov. gen., nov. spec., ein Gametophyt aus dem Chert von Rhynie (Unterdevon, Schottland). - Argumenta Palaeobotanica, 8: 29-45.

Remy, W., Hass, H. (1991b): Langiophyton mackiei nov. gen., nov. spec., ein Gametophyt mit Archegoniophoren aus dem Chert von Rhynie (Unterdevon, Schottland). Argumenta Palaeobotanica, 8: 69-117.

Remy, W., Remy, R. (1980): Lyonophyton rhyniensis nov. gen. et nov. spec., ein Gametophyt aus dem Chert von Rhynie (Unterdevon, Schottland). - Argumenta Palaeobotanica, 6: 37-72.

Renier, A. (1926): La morphologie générale des Ulodendron. - Comptes rendus hebdomadaires des séances de l'Academie, Paris, 182: 408-410.

Renier, A., Stockmans, F., Demanet, F., van Straelen, V. (1938): Flore et faune houillières de Belgique. - Museum Nationale de Belgique, Bruxelles, 102 pp.

Rieseberg, L. H., Wood, T. E., Baack, E. J. (2006): The nature of plant species. - Nature, 440: 524-527. https://doi.org/10.1038/nature04402

Saltzwedel, K. (1969): Revision der Imparipteris ovata (Hoffmann) Gothan. 1. Teil: Typus- und Typoid-Material vom locus typicus. - Argumenta Palaeobotanica, 3: 131-162. https://doi.org/10.1515/bgsl.1969.1969.91.1 
de Saporta, D. (1874): Paléontologie française ou description des fossiles de la France continuée par une réunion de paléontologistes sous la direction d'un comité spécial. 2e série. Végétaux. Plantes jurassiques, vol. 2 [fasc. 15]. - G. Masson, Paris, pp. 194-224.

Scheuchzer, J. J. (1709): Herbarium diluvianum. - D. Gesner, Zurich, 44 pp. https://doi.org/10.5962/bhl.title. 156370

Schimper, W. P. (1869): Traité de paléontologie végétale, 1. - J. B. Baillière et fils, Paris, 740 pp. https://doi.org/10.5962/bhl.title.24942

Schimper, W. P. (1870): Traité de paléontologie végétale, 2. - J. B. Baillière et fils, Paris, 968 pp. https://doi.org/10.5962/bhl.title.24942

Schimper, W. P. (1879): Handbuch der Palæontologie. II. Band. I. Lieferung. - Oldenbourg, Munich, 232 pp.

von Schlotheim, E. F. (1804): Beschreibung merkürdiger Kräuter-Abdrücke und Pflanzen-Versteinerungen. Ein Beitrag zur Flora der Vorwelt. - Becker, Gotha, 68 pp.

von Schlotheim, E. F. (1820): Die Petrefactenkunde auf ihrem jetzigen Standpunkte durch die Beschreibung seiner Sammlung versteinerter und fossiler Überreste des Thier- und Pflanzenreichs der Vorwelt erläutert. - Becker, Gotha, 437 pp.

Schopf, J. M., Wilson, L. R., Bentall, R. (1944): An annotated synopsis of Paleozoic fossil spores and the definition of generic groups. - Report of Investigations, Illinois State Geological Survey, 91: 1-66. https://doi.org/10.5962/bhl.title.61674

Scott, D. H. (1900): On the presence of seed-like organs in certain Palaeozoic lycopods. - Nature, 62: 611-612.

Sen, J. (1958): Notes on the spores of four Carboniferous lycopods. - Micropaleontology, 4: 159-164. https://doi.org/10.2307/1484301

Seward, A. C. (1917): Fossil plants for students of botany and geology. Vol III. - The University Press, Cambridge, $656 \mathrm{pp}$.

Shchegolev, A. K. (1979): Verkhniy karbon severnogo Kavkaza v Zelenchuk-Teberdinskom mezhdurech'e [Upper Carboniferous of the North Caucasus in the ZelenchukTeberda interfluves]. - Akademiya Nauk Ukrainskoy SSR, Institut Geologicheskikh Nauk, Kiev, 194 pp. (in Russian)

Shute, C. H., Cleal, C. J. (2002): Ecology and growth habit of Laveineopteris: a gymnosperm from the Late Carboniferous tropical rain forests. - Palaeontology, 45: 943-972. https://doi.org/10.1111/1475-4983.00270

Sigovini, M., Keppel, E., Tagliapietra, D. (2016): Open Nomenclature in the biodiversity era. - Methods in Ecology and Evolution, 7: 1217-1225. https://doi.org/10.1111/2041-210X.12594

Stafleu, F. A. (1967): Palynology, nomenclature and terminology. - Review of Paleobotany and Palynology, 3: 15-26. https://doi.org/10.1016/0034-6667(67)90035-8

Sternberg, K. M. (1820): Versuch einer geognostisch-botanischen Darstellung der Flora der Vorwelt 1(1). - F. Fleischer, Leipzig, 24 pp.

https://doi.org/10.5962/bhl.title.154066

Sternberg, K. M. (1825): Versuch einer geognostisch-botanischen Darstellung der Flora der Vorwelt 1(4), Tent. E. Brenck's Wittwe, Regensburg, $48+$ xlii pp. https://doi.org/10.5962/bhl.title.154066
Stur, D. (1881): Die Silur-Flora der Etage H-h1 in Böhmen. - Preprint from Sitzungsberichte der Kaiserlichen Akademie der Wissenschaften, Mathematisch-Naturwissenschaftliche Classe, Wien, vol. 84, pp. 1-62 [pp. 330-391 in journal; journal version published in 1882]

Stur, D. (1887): Beiträge zur Kenntnis der Flora der Vorwelt, Bd. II, Abth. 2. Die Carbon-flora der Schatzalerer Schichten, 2, die Calamarien. - Abhandlungen der Kaiserlich-Königlichen Geologischen Reichsanstalt, Wien, 11(2): 1-240.

Sylvester-Bradley, P. C. (1954): Form-genera in paleontology. - Journal of Paleontology, 28: 333-336.

Sylvester-Bradley, P. C. (1958): The definition of the term "parataxon". - Bulletin of Zoological Nomenclature, 15: 972-973.

Taylor, T. N., Krings, M., Taylor, E. L. (2015): Fossil fungi. - Academic Press, London, 382 pp.

Tenchov, Y. G. (1987): Fosilite na B'lgariya I. 1 Paleozoy, Fosilna flora. Megaflora. 1. Chlenestoct"bleni i lepidoftiti [Les fossiles de Bulgarie I. 1 Paleozoïque flore fossile. Megaflora. 1. Sphenopsida et Lycopsida]. - Editions de l'Academie Bulgare des Sciences, Sofia, 165 pp. (in Bulgarian with French summary)

Thomas, B. A. (1967): Ulodendron: Lindley and Hutton and its cuticle. - Annals of Botany, New Series, 31: 775-782. https://doi.org/10.1093/oxfordjournals.aob.a084181

Thomas, B. A. (1970a): Epidermal studies in the interpretation of Lepidodendron species. - Palaeontology, 13: 145-173.

Thomas, B. A. (1970b): A new specimen of Lepidostrobus binneyanus from the Westphalian B of Yorkshire. Pollen et Spores, 12(2): 217-234.

Thomas, B. A. (1978): Carboniferous Lepidodendraceae and Lepidocarpaceae. - Botanical Reviews, 44: 321-364. https://doi.org/10.1007/BF02957853

Thomas, B. A. (1981): Structural adaptations shown by the Lepidocarpaceae. - Review of Palaeobotany and Palynology, 32: 377-388. https://doi.org/10.1016/0034-6667(81)90019-1

Thomas, B. A. (1989): Disarticulated plant fossils. - In: Briggs, D. E. G., Crowther, P. R. (eds), Palaeobiology. A synthesis. Blackwell, Oxford, pp. 421-423.

Thomas, B. A. (1997): Upper Carboniferous herbaceous lycopsids. - Review of Palaeobotany and Palynology, 95: 129-153. https://doi.org/10.1016/S0034-6667(96)00032-2

Thomas, B. A. (2005): A reinvestigation of Selaginella species from the Asturian (Westphalian D) of the Zwickau coalfield, Germany and their assignment to the new sub-genus Hexaphyllum. - Zeitschrift der Deutschen Gesellschaft für Geowissenschaften, 156: 403-414. https://doi.org/10.1127/1860-1804/2005/0156-0403

Thomas, B. A., Appleton, P., Cleal, C. J., Seyfullah, L. J. (2020): The distribution of plant fossils and their palaeoecology in Duckmantian (Bashkirian, Lower Pennsylvanian) strata at Brymbo, North Wales, UK. - Geological Journal, 55: 3179-3207. https://doi.org/10.1002/gj.3529

Thomas, B. A., Brack-Hanes, S. D. (1984): A new approach to family groupings in the lycophytes. - Taxon, 33: 247-255.

https://doi.org/10.2307/1221165 
Thomas, B. A., Cleal, C. J. (1999): Abscission in the fossil record. - In: Kurmann, M. H., Hemsley, A. R. (eds), The Evolution of plant architecture. Royal Botanic Gardens, Kew, pp. 183-203.

Thomas, B. A., Cleal, C. J. (2020): The nomenclature of fossil-taxa representing different preservational states: Lepidodendron as a case-study. - Taxon, 69: 1052-1061. https://doi.org/10.1002/tax.12291

Thomas, B. A., Dytko, A. (1980): Lepidostrobus haslingdenensis: a new species from the Lancashire Millstone Grit. - Geological Journal, 15: 137-142. https://doi.org/10.1002/gj.3350150207

Thomas, B. A., Quansah, N. (1991): The palaeobotanical case for dividing Selaginella (Selaginellaceae, Pteridophyta). - Fern Gazette, 14: 59-64.

Thomas, B. A., Seyfullah, L. J. (2015a): A new look at Lepidodendron ophiurus Brongniart and the recognition of $L$. wingfieldense sp. nov. (Flemingitaceae, Lepidodendrales) from the Langsettian (Bashkirian) of Derbyshire, East Midlands, UK. - Palaeontographica, Abt. B, 292: 23-32. https://doi.org/10.1127/palb/292/2015/23

Thomas, B. A., Seyfullah, L. J. (2015b): Stigmaria Brongniart: a new specimen from Duckmantian (Lower Pennsylvanian) Brymbo (Wrexham, North Wales) together with a review of known casts and how they were preserved. - Geological Magazine, 152: 858-870. https://doi.org/10.1017/S0016756815000035

Thomas, H. H. (1935): Proposed additions to the International Rules of Botanical Nomenclature suggested by British palæobotanists. - Journal of Botany, 73: 111-113.

Thomas, H. H., Bancroft, N. (1913): On the cuticles of some Recent and fossil cycadean fronds. - Transactions of the Linnean Society of London, $2^{\text {nd }}$ Series, Botany, 8: 155-204. https://doi.org/10.1111/j.1095-8339.1913.tb00284.X

Townsend, A., Cleal, C. J., Thomas, B. A. (1998): Bringing the forests back to life - palaeobotanical model making at the National Museums and Galleries of Wales. - Geological Curator, 6: 353-361.

Turland, N. J., Wiersema, J. H., Barrie, F. R., Greuter, W., Hawksworth, D. L., Herendeen, P. S., Knapp, S., Kusber, W.-H., Li, De-zhu, Marhold, K., May, T. W., McNeill, J., Monro, A. M., Prado, J., Price, M. J., Smith, G. F. (eds) (2018): International Code of Nomenclature for algae, fungi, and plants (Shenzhen Code) adopted by the Nineteenth International Botanical Congress Shenzhen, China, July 2017 (Regnum Vegetabile 159). - Koeltz Botanical Books, Glashütten, 254 pp. https://doi.org/10.12705/Code.2018

Unger, F. (1850): Genera et species plantarum fossilium. W. Braunmüller, Vienna, 627 pp.

Van der Zwan, C. J. (1979): Aspects of Late Devonian and Early Carboniferous palynology of southern Ireland. I. The Cyrtospora cristifer morphon. - Review of Palaeobotany and Palynology, 28: 1-20. https://doi.org/10.1016/0034-6667(79)90020-4

de Vere, N., Rich, T. C., Trinder, S. A., Long, C. (2015): DNA barcoding for plants. - In: Batley, J. (ed.), Plant genotyping. Humana Press, New York, pp. 101-118. https://doi.org/10.1007/978-1-4939-1966-6_8

Visscher, H. (1971): The Permian and Triassic of the Kingscourt outlier, Ireland - a palynological investiga- tion related to regional stratigraphical problems in the Permian and Triassic of western Europe. - Geological Survey of Ireland Special Paper, 1: 1-114.

Wang Jun, Pfefferkorn, H. W., Bek, J. (2009): Paratingia wudensis sp. nov., a whole noeggerathialean plant preserved in an earliest Permian air fall tuff in Inner Mongolia, China. American Journal of Botany, 96, 1676-1689. https://doi.org/10.3732/ajb.0800351

Watson, J., Cusack, H. A. (2005): Cycadales of the English Wealden. - Palaeontographical Society Monographs, 158(622): 1-89.

Watson, J., Sincock, C. A. (1992): Bennettitales of the English Wealden. - Palaeontographical Society Monographs, 145(588): 1-228.

Weiss, C. E. (1869): Fossile Flora der jüngsten Steinkohlenformation und des Rothliegenden im Saar-Rhein-Gebiete. Band I. - A. Henry, Bonn, 100 pp.

Weiss, C. E. (1876): Zur fossilen Flora. SteinkohlenCalamarien mit besonderer Berücksichtigung ihrer Fructificationen. - Abhandlungen zur geologischen Specialkarte von Preussen und Thüringischen Staaten, 2(1): $1-149$.

Weiss, C. E. (1884): Beiträge zur fossilen Flora. III. Steinkohlen-Calamarien. - Abhandlungen zur geologischen Specialkarte von Preussen und den Thüringischen Staaten, 5(2): 1-204.

Williams, D. M., Ebach, M. E. (2020): Cladistics. A guide to biological classification ( $3^{\text {rd }}$ edition). - Cambridge University Press, Cambridge, $435 \mathrm{pp}$. https://doi.org/10.1017/9781139047678

Williamson, W. C. (1887): A monograph on the morphology and histology of Stigmaria ficoides. - Palaeontographical Society Monographs, 40(189): 1-62. https://doi.org/10.1080/02693445.1887.12027992

Zalessky, M. D. (1911): Izuchenie anatomii Dadoxylon Tchihatcheffi Göppert sp. [Study of the anatomy of Dadoxylon Tchihatcheffi Göppert sp.]. - Trudy Geologicheskogo komiteta, 68: 1-29. (in Russian)

Zeiller, R. (1906): Bassin houiller et Permien de Blanzy et du Creusot, fasc. II, Flore fossile. - Études des Gîtes Mineraux de la France, Paris, 265 pp.

Zhang Hong (1987): [Palaeobotany]. - In: Institute of Geology Exploration (eds), [Sedimentary environment of the coal-bearing strata in Pinglu-Shuixian mining area, China]. Shaanxi Peoples Education Publishing House, Xi'an, pp. 195-204. (in Chinese)

Zijlstra, G., van Konijnenburg-van Cittert, J. H. A. (2020): Proposals to conserve the name Williamsonia with a conserved type and $W$. gigas TM Harris against $W$. gigas (Lindl. \& Hutton) Carruth. (fossil Cycadophyta: Bennettitales). - Taxon, 69: 1376-1378. https://doi.org/10.1002/tax.12408

Zodrow, E. L., Cleal, C. J. (1988): The structure of the Carboniferous pteridosperm frond Neuropteris ovata Hoffmann. - Palaeontographica, Abt. B, 208: 105-124.

Zodrow, E. L., Gao Zhifeng (1991): Leeites oblongifolis nov. gen. et sp. (sphenophyllaean, Carboniferous), Sydney Coalfield, Nova Scotia, Canada. - Palaeontographica, Abt. B, 223: 61-80.

https://doi.org/10.1017/S0016756800060477 